\title{
Postmodern Romantik Illișkiler ve Reklam: Tinder Örneği
}

\author{
Aysel TAPAN 1
}

Öz

Gündelik hayatın önemli bir parçası haline gelen mobil flört uygulamaları, romantik ilişkilerin doğasını hızla değiştirmeye devam etmektedir. Kimileri mobil flört uygulamalarını "aşkın bayağılaşması" olarak yorumlarken, bazıları bu flört etme biçimlerindeki derin değişim ve dönüşümü dijital dünyanın kaçınılmaz sonuçlarından biri olarak görmektedir. Bu çalışmanın amacı ise teknolojik gelişmelerin etkisiyle cinsler arası ilişkide flört etme biçimlerindeki değişimler ile tüketim arasındaki ilişkiyi ortaya koyabilmektir. Bu bağlamda romantik ilişkilerin tarihsel bir düzlemde anlamına ve değişimine ilişkin literatür gözden geçirilerek, coğrafi konum tabanlı flört uygulamalarının reklam sektörüne yarattığı fırsatlar değerlendirilmiştir. Çalışma kapsamında postmodern romantik ilişkilerin, dijital yaşam tarzları, kültür ve tüketimle olan bağı çerçevesinde, konum tabanlı sosyal ağ uygulamaları arasında en popülerlerden biri olan mobil flört uygulaması Tinder'da yayınlanan reklamlar, niteliksel ve niceliksel içerik analizi yöntemiyle incelenmiştir. Sonuç olarak, reklam mesajlarının büyük oranda lüks ve sembolik tüketime ilişkin anlam ve sembollerle işaret ettiği fakat markaların coğrafi konuma uyumlu reklam stratejileri geliştirmedikleri görülmüştür. Elde edilen veriler ayrıca, küresel bir eğilim olan ve kısa dönemli ilişkileri vurgulayan Tinder'da yayınlanan reklamlarda, geleneksel romantik ilişkileri yeniden üreten anlam ve sembollerin yer aldığını ortaya koymaktadır.

Anahtar Kelimeler: Konum tabanlı sosyal ağ uygulamaları, konum tabanlı reklam, mobil flört uygulamaları, kültür, Tinder.

Atıf: Tapan, A. (2019). Postmodern Romantik Illișkiler ve Reklam: Tinder Örneği. Akdeniz Üniversitesi İletișim Fakültesi Dergisi, Haziran (31), s. 32-59

1 Araştırma Görevlisi, Kocaeli Üniversitesi, İletişim Fakültesi, Reklamcılık Bölümü, a_tapan@hotmail.com, ORCID Numarası: 0000-0002-4270-4028. 


\title{
Postmodern Romantic Relations and Advertising: Tinder Case Study
}

\begin{abstract}
Mobile flirting applications, which have become an important part of everyday life, continue to change the nature of romantic relations rapidly. Some interpret mobile flirting practices as "banalization of love", while others see these deep changes and transformation in flirtation forms as one of the inevitable consequences of the digital world. The aim of this study is to reveal the relationship between consumption and flirtation forms in the relationship between sexes with the effect of technological developments. In this context, the literature on the meaning and change of romantic relations in a historical plane has been reviewed, and the opportunities created by geolocation based dating applications for advertising sector have been evaluated. Within the context of postmodern romantic relations, digital lifestyles, culture and consumption, the advertisements published in the mobile flirting application Tinder, which is one of the most popular location-based social networking applications have been examined by qualitative and quantitative content analysis method. Consequently, advertising messages indicate meanings and symbols that are relevant to luxury and symbolic consumption, but brands do not develop geographic location-based advertising strategies. The data also show that published ads in Tinder which as a global tendency, and emphasizes short-term relationships, foreground meanings and symbols that reproduce traditional romantic relationships.
\end{abstract}

Keywords: Geo-Social Networking Apps, Location Based Advertising (LBA), mobile dating application, culture, Tinder. 


\section{Giriș}

C CReklam kapitalizmin şiiridir" (Paterson, 2006, s. 37) cümlesinin anlamının en somut şekilde gözlemlenebildiği mobil flört uygulamalarının, postmodern romantik ilişkilerin odak noktasında yer aldığını söyleyebiliriz. Mobil flört uygulamaları, hızla yükselmeye devam eden ve artık sonuçları çok da kestirilemeyen dijital dünyada, insanların aşkı ya da cinselliği bulma arayışlarının sosyo-ekonomik ve kültürel bir yansımasıdır. Son zamanların en popüler mobil flört uygulaması olan "kısa dönemli cinsel ilişkiler" e vurgu yapan ve 2012'de kurulan konum tabanlı mobil flört uyguları arasında lider konumda olan Tinder, 2018 istatistiklerine göre yaklaşık 57 milyon kullanıcıya sahiptir.

Bireyin sonsuz sayıda seçenek ve tercih kültürüyle çevrelendiği günümüzde, partner seçimi yapmanın ya da yapmamanın belirgin bir şekilde kullanıcıya sunulduğu, Facebook ya da telefon numarası ile giriş yapılabilen Tinder'da, kullanıcılar bir kişiyi beğendiğinde ekranı sağa, beğenmediğinde ise sola kaydırmaktadır. Her iki kullanıcı da ekranı sağa kaydırırsa bir "eşleşme" olmaktadır ve kullanıcılar birbirlerine mesaj yazabilmektedirler. Bireyler, kullanıcı profili gibi karşılarına çıkan reklamları yukarı kaydırınca da markanın web sitesine yönlendirilmektedirler.

Kapitalizmin kültürel görüngüleri bağlamında, aşk ideolojisi ve tüketim arasındaki bağ, kapitalizmin yükseliş sürecinin odak noktasında yer almaktadır. Yaşam tarzı kalıplarının her bir zerresine işlenen aşk ideolojisi, modern dünyanın doğuşuyla tüketimin en derin noktalarına demirlenmiştir. Aşkın bir illüzyon olduğu yönündeki iddiayı güçlendiren, mahremiyetin ortadan kalkmasının ve gösterinin olumlandığı mobil flört uygulamaları, aşk ideolojisi ve kapitalizm arasındaki derin ilişkinin somut göstergelerinden biridir.

Kısa dönemli ilişkilere vurgu yapan postmodern romantik iliş̧ilerin içine gömüldüğü mobil flört uygulamalarının temel propagandası, ilişki kurmanın/aşık olmanın ortaya çıkarabileceği riskin azaltılmasıdır. Sonsuz seçenek arasında "seçim" yapma ve her zaman "eşleşmeyi kaldır" diyebilme özgürlüğü yanılsamasıyla reklamlarla karşılaşan mobil flört uygulamaları kullanıcıları ile marka arasında pozitif duygusal bağlııklar yaratabilmek için aşk ideolojisinin ve değişen flört etme biçimlerinin kültürel yansımaları dikkate alınmalıdır.

İnteraktif reklam stratejilerini olanaklı kılan konum tabanlı sosyal ağ uygulamaları (GeoSocial Networking Apps) dijital dünyada uzun süredir özellikle bireyi detaylı bir şekilde tanımlamaya ve anlamaya çalışan reklam endüstrisi tarafından bir "devrim" olarak görülmektedir. Konum tabanlı mobil reklamlar (Location-based mobile advertising) markalara, reklam mesaj ve tasarımlarını konum ile uyumlu hale getirerek bireylere istediği zaman ve yerde ulaşma imkanı sunmaktadır. İsteğe bağlı olarak konum bildirilmeyen ve her kullanıldığında konum bilgisinin güncellendiği Tinder gibi mobil flört uygulamalarının sunduğu gerçek zamanlı konum verisi, uygulamanın özellikleri ve kullanım amaçları, markalara konum tabanlı reklam stratejileri geliştirmek için önemli fırsatlar sunmaktadır. 
ağlarda olduğu gibi kimliklerini tüketilen ve sergilenen metalardan yola çıkarak inşa eden Tinder kullanıcılarının, hangi anlam ve sembollere vurgu yapan reklamlara maruz kaldıklarını belirlemektir. Bu temel amaç çerçevesinde, sosyal kurumlara, gelenek ve göreneklere uygun romantik ilişkilerin dışına çıkan küresel bir uygulama olan Tinder'da, Türk kültürünün etkisiyle aile kurumuna, toplumun değer ve normlarına uygun romantik ilişkilere dikkat çeken reklam mesajlarının var olup olmadığı araştırılmıştır. Ayrıca, yerel markaların Tinder'ı kullanım oranı ve nasıl kullandıkları değerlendirilmiştir. Bu çerçevede, Tinder gibi statü odaklı ve konum tabanlı uygulamaların özellikle yerel markalar için ortaya çıkarabileceği avantajlar tartışılmıştır.

\section{Postmodern Romantik İlișkilerde Kimlik Bunalımı}

Tinder kullanıcılarının, seçimlerini nasıl ve neden yaptığını anlayabilmek için aşkın, diyalektik düzende yani ikili düzende bir kültür iliş̧isi ve kültür tarafından en az diğer eylemler kadar şekillendirildiği göz önünde bulundurulmalıdır. İnsanların cinsel dürtüleri de kültürel engel ve mekanizmalar tarafından biçimlendirilmektedir. Özgür düşünce, eylem ve seçişler alanı olan aşka ilişkin her şey temelde belli bir toplumun insan anlayışında açıklığa kavuşabilir. Çünkü deneyim, daima kurumlar bünyesinde yaşanır ve onlar tarafından düzenlenir. Modernitenin kilit kavramlarından biri olan "seçim" kavramı, aşkın modernitede geçirdiği değişimi anlamanın en iyi yollarından biridir ve flört etmenin nasıl değiştiğini yansıtmaktadır. Aşk, seçimin modernitedeki toplumsal temeli hakkında önemli bilgiler verebilmektedir. Eğer seçim modern bireyin temel özelliğiyse, insanların bir ilişkiye başlamayı nasıl ve neden seçtiği ya da seçmediği, aşkı kültür tarafından biçimlenen modernitenin bir deneyimi olarak anlamak için oldukça önemlidir (Malinowsky, 1983, s. 14-19; Timuçin, 2010, s. 8-31; Illouz, 2013, s. 33-40; May, 2010). Kolektif kurallarla sınırlanmadığı ya da önceden belirlenmediği çapta özgür diye adlandırılan bu bireysel seçim, çağdaş toplumlarda geleneksel olarak katkıda bulunan unsurlardan sadece bir tanesine yani sevgiye dayandırılmıştır ve çağdaş toplumun evliliği geçici bir zevk olan romantikliğe dayandırmaya çalışması başarısızlığa uğramıştır (Rougemont, 1983, s.84-87).

Çağdaş toplum, aile çerçevesi içinde cinsel isteklerin tatminini sağlayarak "romantik kur yapma ve sevgi eşi seçimini” evlilik içinde toplamıştır. Bu geçiş döneminin getirdiği kesintilerin ve bozuklukların en karakteristiği ise Viktorya çağıdır. Viktorya dönemi insanı, sekse karışmadan aşkı elde etmeyi aradı; modern insan ise aşka karışmadan seksi elde etmeyi arıyor. Iki ilişki şeklinin tamamen birbirini dışlaması, günümüzdeki ilişkilerinde de "kesinti ve bozuklukları" olduğunun altını çizmektedir. Modern insanın aşka karışmadan seksi elde etme isteğini "şizoid" kavramıyla açıklamak mümkün olabilir. "Şizoid" terimi, dünyayla ilişkisini kesme, yakın ilişkilerden kaçınma, hissedememe anlamındadır. Şizoid insan teknolojik insanın doğal bir ürünüdür, bir yaşam biçimidir ve giderek yaygınlaşmaktadır. Kayıtsızlık ve şizoid dünya birbirilerinin nedeni ve sonucu olarak el ele gitmektedirler (Dell, 1983, s.48; May, 2010, s.13-33). Mobil flört uygulamalarını da bu eğilimin hem nedeni hem de sonucu olarak görmek mümkündür. 
Aşk, geçmişte yaşamın çıkmazlarına bir çözüm olarak görülmesine karşın, günümüzde bizzat kendisi sorun haline gelmiştir. Yani modern bireyin temel özelliklerinden biri olan seçimin kendisi sorunlu bir durum haline gelmiştir. Artık sorun, ne yapılacağına karar vermek değil, nasıl karar verileceğine karar vermektir. Bireyleri yönlendiren eski mitler ve simgeler yoktur artık. İradesini kullanmayan birey diğerlerini kaybedeceğinden korktuğu için aslında bir şeyi veya kişiyi seçememektedir (May, 2010, s.9-37). Mobil flört uygulamalarını kullanan "kayıtsız ve kaygılı" birey, sanal olarak bir seçim yaptığı ya da seçildiği yanılsamasını yaşamaktadır. Kaygı bozukluğu, hissetme yetersizliği ve kayıtsızlık, kişinin içinde bulunduğu boşluğu yeniden ve yeniden üretmektedir.

Modernite, cinsiyet eşitliği ve cinsel özgürlük gibi iki politik ideali yakınlığın merkezine koyarak, aşkı nezaket ve saygı ritüellerinden sıyırmış ve onun şimdiye dek büründüğü gizemli havayı dağıtmıştır (Illouz, 2013, s.25). Özgür ve spontane bir postmodern-ben vurgusu, bir yandan gerçekliğin büyüleyici bir biçimde üretilmesi için akıl almaz imkânlar içeren, öte yandan ekonominin ve toplumun dayandığı bütün yapıların ve değerlerin çözülmesi karşısında anlamlı bir tepkiyi ifade eder gibi görünen yaşam deneyimine verilen bir yanıttır (Funk, 2013, s.12). Modern çağla birlikte kamu mülkiyetinden özel mülkiyete geçen cinsellik (Eagleton, 2014, s.16) konusunda ileriyi göremeyen liberalizmde farkına varamadığımız şey, bireyi sınırsız ve boş bir özgürlükler denizine atmanın kendi başına özgürlük vermediği, aksine iç çatışma olasılıklarını artırdığıdır. Kendimizi adadığımız cinsel özgürlük tümüyle insancıl olmaktan uzak kalmıştır (May, 2010, s.47). Mobil flört uygulamalarında bireyler de cinsel özgürlük idealini tek gecelik, anlamsız ve özel olmayan cinsel ilişki olarak yorumlayabilmektedirler.

19. yüzyılda yaşanan radikal siyasi, toplumsal ve bilimsel değişiklikler inancı yeniden şekillendirmiştir. Nietzsche (2003), "Tanrı öldü ve ölü kalacak çünkü biz onu öldürdük" diyerek bir anlam krizi ilan eder. Ona göre, kendi kaderimizi yaratma konusundaki özgürlük, dini inanç kaybı, insan varlığında anlamın kaybolmasından farksız olacaktı. Modernist düşünce, Aydınlanma'yla birlikte Tanrı'nın doldurduğu boşluğu doldurmaya çalışmıştır ve bu süreçte en işlevsel araç kültür olmuştur. Önemli olan gündelik pratiklerde vücut bulan inanç ya da inançsızlıklardır (Eagleton, 2014, s.23). Mobil uygulamalar yoluyla flört etme, dijital dünyanın ikilemleri ve karmaşasıyla çevrelenmiş birey için anlam kriziyle baş etme yollarından biri olabilir mi? Bu bağlamda anlama ilişkin şu iddiaları da göz önünde bulundurmalıyız: Anlam, bir taraftan sosyo-kültürel ve tarihsel bağlamın, diğer taraftan kişisel psikodinamik ve psikobiyografik bağlamın girift bir karışımıdır. Ruh, kültür ve toplum esas itibariyle iç içedir (Chodorow, 2007, s. 13-236). Bireyin esas problemi "boşluk" duygusudur. Freud'un sorunun kaynağı olarak gördüğü cinsel tabular artık eski katılıklarını kaybetmiş durumdalar. Sorun artık toplumsal tabular veya cinsellik hakkında suçluluk duyuyor olmaktan çıkıp, cinsel ilişkinin anlamsız, mekanik bir deneyim haline gelmesine doğru gitmektedir. Ayrıca, yalnızlık ve boşluk her zaman yan yanadır ve aynı endişe halinin değişik iki aşamasıdırlar. Birey hayatla yüzleşebilmek adına diğer insanlarla ilişki halinde olmaya intiyaç duyar. Varlığını sürekli hissettiği yalnızlığın bir parçasını da bu gerçek teşkil eder (May, 2010, s.16-29). Boşlukta ve yalnız olduğunu hisseden sosyal ağ kullanıcıları, diğerleriyle ilişki halinde olma yanılsamasıyla boşluk ve yalnızlık duygularını gidermeye çalışmaktadırlar. 
Mobil flört uygulamalarında eşleştiğiniz kişinin, yaşanan ilişkilerin düş mü kabus mu olduğu sorusu akademik literatürde çoğunlukla konum tabanlı mobil uygulamaların doğasından kaynaklanan dijital güvenlik odaklı risk bağlamında tartışılmaktadır. Fakat, durumun bir de ruhsal/psikolojik risk boyutu vardır. Dijital dünyanın kıskacına düşen birey, aşkın yarattığı ruhsal risklerden kaçınma propagandasıyla çevrelenmiştir. Fransız felsefeci Alain Badiou ve postmodern düşünür Slavoj Zizek, flört uygulamalarından örnekler vererek acının/riskin aşkın doğal bir parçası olduğuna dikkat çekmektedirler.

Badiou, "Aşka Övgü” kitabında aşkı, "kozmopolit, bulanık, eşeyli, sınırları ve toplumsal durumları hiçe sayan güç" olarak tanımlayarak aşkın tehdit altında olduğunu Paris'te "Meetic" adlı bir tanışma sitesinin reklam kampanyasıyla örneklendirmektedir. "Aşk koçluğu" hizmeti de sunan Meetic, "Aşkı rastlantıya bırakmayın”, "Aşka düşmeden aşık olunabilir" sloganlarını kullandığı reklam kampanyasında, "Acı çekmeden de pekâlâ aşık olabilirsiniz" mesajını vermiştir. Risksiz bir düzende aşkın yaşamın zenginliği olmaktan çıkacağını söyleyen Badiou, ABD ordusunun "sıfır ölümlü" savaş propagandasıyla, Meetic'in "risksiz aşk" propagandası arasındaki benzerliğe dikkat çekmektedir. Aşk söylemi riskin aslında başkaları için geçerli olduğunu söylemeye dayanmaktadır: "Acı çekiyorsa demek ki çağdaş yaşama ayak uyduramamış biridir" (Badiou ve Truong, 2011, s.15-16).

Zizek de ABD'de bir evlilik ajansının reklamından örnek vererek risksiz aşık olma propagandasının altını çizmektedir: "Biz 'düşmeden' aşık olmanızı sağlayacağız" demektedir evlilik ajansı. "Fakat düşmek aşk denen şeydir. Aşkın büyüsü şartlara bağlıdır. Ben bu noktada seksin yok olduğunu iddia ediyorum. İnsanlar artık çok daha az seks istiyorlar. Onlar keyif istiyorlar" diyen Zizek, mastürbatif seksüel olmayan ilişkilerin keyfine dikkat çekmektedir (Zizek, 2012).

Badiou'ya göre de aşkın iki temel düşmanı vardır: sigorta sözleşmesi güvenliği ve kısıtlı zevklerin rahatlığı. Mobil flört uygulamalarının da aşkın bu iki "düşmanını" inşa ettiğini söylemek mümkündür. Badiou ayrıca, aşk üstüne üç ana felsefe olduğunu söylemektedir: karşılaşmanın esrikliğine yoğunlaşan romantik düşünce, aşkı bir sözleşme olarak gören düşünce, aşkı bir yanılsama olarak değerlendiren kuşkucu düşünce (Badiou ve Truong, 2011, s.16-26). Çalışmanın inceleme nesnesi olan Tinder uygulaması, özellikle aşkı bir sözleşme olarak sunan düşünceye örnek olarak gösterilebilir. Bu sözleşmede kullanıcılar, ne vaatte bulunur ne de vaat bekler fakat isteklerini kısa biyografilerinde belirtirler. Ayrıca, olası partnerlere karşı bütün kapıları her daim açık tutmak isterler yani "özel” kişi olmak istemezler. Çünkü flörtler tehlikelidir, çünkü kendilerine özgü bir şekilde gerçek ilişkiye inanırlar. Burada inanmaktan kasıt "varmış gibi davranmaktır". Flört, inandırıcı olmayanın büyüsüne kapılmamıza izin verir. Bir belirsizlik oyunu ve ikna edilme intiyacı yaratarak durmadan sürpriz düşüncesiyle oynar (Phillips, 1997, s.13-15). Mobil flört uygulamalarında eşleşmeyi "kaldır" tuşuna basmak her zaman mümkündür. Bir ağda talep üzerine bağlantıya girilir, iradi olarak kesilebilir. Bauman'ın vurguladığı gibi, (2012, s.13) bağlantılar "sanal ilişkiler" dir. "Gerçek ilişkiler" in tersine, "sanal ilişki" ye girmek ve bu ilişkiden çıkmak kolaydır. Ağır, yavaş, hareketli, atıl ve muğlâk, "ciddi şeyler" le kıyaslandığında, şık ve bakımlı 
görünürler, bunları kullanmak kolay gözükür, "kullanıcı dostu" durlar.

Öte yandan sosyal hayat, gelenekler ve görenekler, teknolojiye direnebilir ve teknolojiye aynı hızla ayak uydurmayabilir. Fakat Tinder gibi mecralar bu dönüşümde katalizör olurlar. En fazla kullanıcıya sahip olan sosyal ağ Facebook da Mayıs 2018'de Tinder'a alternatif olarak risk algısını azaltmak amacıyla gelenek ve göreneklere uygun "uzun süreli ilişki" arayan kullanıcılarının kendisine partner bulabilmek için "özel" bir profil oluşturabileceğini ve bu profilin kullanıcıların arkadaşlarına gösterilmeyeceğini açıkladı. Facebook kurucusu Zuckerberg, "Yapacağımız uygulama ile gerçek ve uzun dönemli ilişkiler inşa etmek için çalışıyoruz, belki de hepimiz için en çok anlam taşıyan o kişiyi bulmak için" açıklamasını yapmıştır. Zuckerberg'in yaptığı açıklamada "gerçeklik", "inşa etmek”, "anlam”, "özel” kelimelerine vurgu yaptığı dikkat çekmektedir. Çünkü gerçeklik sosyal olarak inşa edilmektedir. Gündelik hayatın gerçekliği düzenlenmiş bir gerçekliktir. Birey, kendi "gerçeklik" lerini ve kendi "bilgi" sini bir toplumdan bir diğerine değişen oldukça farklı "gerçeklikleri" verili bir şey olarak kabul eder. Spesifik "gerçeklik" ve "bilgi" kümelenmeleri, spesifik sosyal kontekstlerle ilintilidir ve Mannheim'ın belirttiği gibi, (2002) hiçbir insanı düşünce, içinde bulunduğu sosyal kontekstin ideolojikleştirici etkisinden muaf olmaz sadece hafifletilebilir (Berger ve Luckmann, 2008, s.15-35). Tinder gibi sosyal kurumlara, gelenek ve göreneklere uygun romantik ilişkilerin dışına çıkan ve "kısa dönemli seks" vaadi sunan bir sosyal ağ uygulamasında bile ideolojikleştirici etki sadece hafifletilebilmektedir. Facebook ise romantik ilişkileri ideolojikleştirmeye uygun bir hale getireceğini açıklamıştır. Zuckerberg, geleneksel sosyal hayatın dokusuna uygun karşıt bir direnç alanı geliştirmeye çalışmaktadır.

Ayrıca mobil flört uygulamaları, romantik ilişkileri ve cinselliği insanlığın yaratmış olduğu "ölüm bizi ayırana kadar" şeklindeki mitik anlamdaki ulaşılmaz aşk tarifinin ve hayalinin tamamen dışına çıkarmıştır. 19. yüzyılda aşkın kamusal alana taşınmasından "tek gece sevişmek/one night stand" kod adı altında "anlamsız" tek gecelik ilişkilerin kamusal alanda bahsedildiği bir duruma gelinmiştir artık. "Dikizleme Kültürü” nün (Niedzviecki, 2009) zevkiyle ve sadece bir tıkla flört edebilmenin hazzıyla yasak olan serbeste, ayıp olan makbule, akla gelmeyen kabul edilebilire doğru yön değiştiriyor. Birbirlerine karşıtık içinde kurulagelmiş ve karşılıklı temastan yoksunmuş gibi tahayyül edilen "mahrem olan" ile "toplumsal olan" iç içe geçiyor ve mahremiyet kamusallaşırken, kamusal alan da bir zamanlar mahrem olarak adlandırılıp, sessizleştirilen meselelere kucak açıyor (Özbay, Terzioğlu ve Yasin, 2011, s.11). "Mahremiyet Politikası"nı web sitesinde detaylı bir şekilde anlatan Tinder, kullanıcıların bir günde kaç defa ekranı sağa ya da sola kaydırdığından, birbirlerine gönderdikleri mesajların karakter sayısına kadar birçok veriyi kaydetmektedir ve bu verileri üçüncü taraflarla kullanım hakkına sahiptir.

\section{Mobil Flört Uygulamalarında Benlik Sunumu}

Eski dünyadan yeni dünyaya geçişte modernitenin "Eski" olanı din, cemaat, düzen ve istikrardı. "Yeni” ise nefes kesici değişim, sekülerlik, cemaat bağlarının çözülmesi, eşitlik taleplerinin artması ve kimlik hakkındaki rahatsızıı verici belirsizlikti. Modernite, 
birçok sosyoloğun hemfikir olduğu üzere, heyecan verici intimaller teklif etmekle birlikte anlamlı hayatlar yaşama becerimize kaygı verici riskler de getirmiştir (Illouz, 2013, s.23).

Fiziksel olarak aynı ortamda bulunmayan bireylerin yarattığı benliklerin ve rollerin, dijital dünyanın en muammalı konularından biri olduğunu söyleyebiliriz. "Hızla bitirip yeniden başlama becerisi” geliştiren mobil flört uygulaması kullanıcılarının yarattığı çevrimiçi benlik ve rollerin, internet, bilgi akışı ve sosyal medyanın etkilerine dikkat çeken Bauman'ın "Akışkan Modern Dünyadan 44 Mektup” kitabında "akışkan modern dünya"yı tanımlarken kullandığı, "kalabalık yalnızlık", "elektronik nesil”, "özgürlüklerin sahte yükselişi”, "çığııından çıkan fobiler" gibi nitelemelerle yakından ilişkili olduğunu söyleyebiliriz (Bauman, 2012, s.21).

Goffman'a göre, (2014, s.16) toplumsal rollerin içselleştirilmesiyle tanımlanan gündelik hayatın "pratik deneyimi" yoluyla, bireylerin sahne önü ve sahne arkası benlikler yaratarak rollerini idare etmeyi ve onların arasında müzakere yapmayı öğrenmektedir. Böyle yaparak bireyler, yaratıcı bir şekilde gündelik hayatlarını yönlendirebilmekte, kanıksanmışıklarını kırmak için uzamlar yaratarak onu çekilebilir bir hale getirmektedirler. Benlik, belirli mekanlarda gerçekleşen performansların bir derlemesidir. İnsanlar bulundukları ortama yeni birisi girdiği zaman genelde ya o kişi hakkında bilgi edinme ya da halihazırda sahip oldukları bilgileri kullanma çabası içine girerler. En merak edilenler o kişinin genel toplumsal ve iktisadi durumu, kendini nasıl gördüğü, çevresine karşı takındığı tavır, işinde usta olup olmadığı ve güvenilir olup olmadığı gibi konulardır. Dijital dünyada da bu durumun geçerli olduğunu görmekteyiz. Çünkü anonimlik, aldatma gibi antisosyal davranış potansiyelini arttırmaktadır (Guadagno, Okdie ve Kruse, 2011). Ranzini ve Lutz tarafından yapılan bir araştırmaya göre, (2017) Tinder'da yanıltıcı, aldatıcı benlik sunumu özellikle öz saygı, eğitim ve cinsel yönelim faktörlerinden etkilenmektedir. Yüksek eğitimli kullanıcıların gerçek benlik sunumları daha düşük düzeydedir. Öz saygısı düşük olan ve eşcinsel, biseksüel veya "öteki" olarak nitelendirilen kullanıcıların benlik sunumunda aldatıcı olma olasılıkları yüksektir. Tinder kullanıcıların ayrıca kısa biyografilerle ve fotoğraflarla yaşam tarzına ilişkin bilgiler sunarak statü, para ve güven unsurlarına vurgu yaptıklarını söylemek mümkündür. Çünkü para, cazip kılmayı sağlayan paradoksal bir güce sahiptir (Zizek, 2005, s.28). Para, nesneleri doğal anlamlarından uzaklaştırarak, işlevlerinden ve bireysel zevklerden bağımsız oldukları yeni, kültürel bir söyleme dönüştürür (Chaney, 1999, s.59). GlobalWeblndex 2015 (McGrath, 2015) istatistiklerine göre Tinder kullanıcılarının \%41'i 25-34 yaş aralığındadır. Kullanıcıların \%34'ünün geliri orta, \%29'unun geliri ise üst düzey olarak kaydedilmiştir.

Kişi kendini başkalarına sunduğunda, performansı toplumun resmi olarak onaylanmış değerlerini, davranışlarından çok daha fazla içerir ve temsil eder. Toplumsal sınıflarla özdeşleşmiş belki de en önemli işaret aracı maddi varlığını ifadesi olan statü simgeleridir (Goffman, 2014, s.45-46). Söz konusu kişi hakkındaki bu bilgiler gözlemcilerin kendilerinden ne beklendiği ve kendilerinin karşılarındaki insandan ne bekleyebilecekleri üzerine önbilgiler sağlayarak ilişkinin tanımını yapmalarına olanak 
verir. Bu bağlamda, mobil flört uygulamalarında da her şey rastlantısal ve bir o kadar da risksiz görünse de Badiou, Bauman ve Zizek'in altını çizdiği "riskin tamamen ortadan kalkmaması" nedeniyle kullanıcıların aldıkları bilgilerle ilişki durumunun tanımını yapmaya ve beklentilerinin çerçevesini çizmeye çalışırlar.

Kişinin kendini ifade etme derecesi (dolayısıyla da izlenim bırakma kabiliyeti) ve özü birbirinden çok farklı iki tür işaretleşme faaliyeti içerir: verdiği izlenim ve yaydığı izlenim. Bu ayrım yalnızca işin başında anlamlıdır. Tabii ki, kişi bu iki tür iletişim aracılığıyla bilerek yanlış bilgi verebilir. Bu yollardan ilki aldatma, ikincisi ise rol yapma içerir (Goffman, 2014, s.16). Mobil flört uygulamalarında ve diğer sosyal medya ağlarında kullanıcılar bu iki tür eylemi yani aldatma ve rol yapma eylemlerini gerçekleştirebilmektedirler. Bu noktada nasıl ki yaşamımızı çıkarımlarla devam ettiririz, kullanıcılar da Tinder'da eşleşme öncesi fotoğraflarla, demografik ve biyografik metinlerle eşleşme sonrası ise yazdıkları anlık mesajlarla birbirleri hakkında çıkarımlarda bulunmaya çalışmaktadırlar. Birbirlerine "Neler beni bir birey olarak tanımlar?" sorusunun cevabını vermeye çalışan kullanıcılar, hiç kimsenin artık diğerleri tarafından tanınamadığı bir toplumda, kendi gerçekliğini tanıyamaz hale gelmektedirler (Debord, 1996, s.114).

Mobil flört uygulamalarının bir başka boyutu da ego tatminidir. Yenilik tutkusuyla farklı bireyler tarafından beğenilmek (like) hatta çok beğenilmek (super like) isteyen Tinder kullanıcıları, bu beğenilme isteğine paralel olarak daha çok göstermek isterler. Gösteri, kendini tartışılmaz ve erişilmez devasa bir olumluluk olarak sunar. "Görünen şey iyidir, iyi olan şey görünür" (Deboard, 1996: s.16). Postmodern toplumda, temsil o kadar güçlüdür ki gündelik deneyimin ana formu haline gelmiştir (Bennett, 2013, s.65). Ranzini ve Lutz'un (2017) Tinder kullanıcılarının kendilerini nasıl sunduklarını ortaya koymak için yaptıkları araştırmaya göre öz saygı, gerçek benlik sunumunu teşvik eden ve yanıltıcı benlik sunumunu azaltan en önemli psikolojik yordayıcıdır. Demografik özellikler ve psikolojik geçmiş yaşantılar Tinder kullanım nedenini -seks, arkadaşlık, seyahat, kendini doğrulama-kanıtlama, eğlence- etkilemektedir ve cinsler arasında belirgin farklılıklar görülmektedir. Kadınlar Tinder'ı özellikle arkadaşıı ve kendini doğrulama-kanıtlama, erkekler ise seks, seyahat ve ilişki kurmak amacıyla kullanmaktadır.

\section{3. “Süper” Eșleșmeyi Ararken Reklamlar}

"Süper Beğenme/ Super Like" ile "mükemmel” kişi ile eşleşmek ve çevrimiçi bir ilişki için yeniden ve yeniden deneyen Tinder kullanıcılarının, profilleri inceleyip ekranı sağa ya da sola kaydırırken, kullanıcı profili gibi karşılarına çıkan reklamları da markanın web sitesi için yukarıya kaydırmaları gerekmektedir. Illouz'nin de belirttiği gibi, (2013, s.26) aşkı incelemek modernitenin özünün ve temelinin dışında değil merkezindedir. Cinsellik, ahlâkî normlardan kopuk hâle gelmiş ve bireyselleşen yaşam tarzlarına ve yaşam projelerine dahil olurken, kapitalist kültürel dil de heteroseksüel romantik ilişkilere büyük ölçüde nüfus etmiştir. Aşk artık aktörlerin ekonomik ve duygusal eğilimlerini tek bir kültürel temelde birleştirerek akılcı ve stratejik çıkarları içerir hâle gelmiştir. 
İhtiyaçların kitlesel tüketimi ve kitlesel üretimi üzerinde temellenen "tüketim toplumu" nda tüketim ürün ve mallarını imal edenler, aynı zamanda tüketicileri de imâl etmeye çabalarlar. Lefebvre'ye göre (2010, s.18) büyük ölçüde de bunu başarırlar. Tüketici arzu duymaz. Onun tuhaf biçimde "motive edilen davranışları" vardır. Tüketici reklamın, satış hizmetlerinin ya da toplumsal prestij gereklerinin verdiği telkinlere ya da "emirlere" itaat eder. Bu noktada modern ve postmodern tüketicinin analizi bağlamında, tüketimin rasyonel ekonomik boyutu ve sembolik boyutu arasında bir ayrıma vurgu yapmak istediğimizde öncelikle "Aylak Sınıfı Teorisi” ile 1899'da tüketimin gösteriş amacı ile yapılabildiğini ileri süren Veblen'in öykülenme modeli (emulation model) karşımıza çıkmaktadır. Veblen, tüketimin sembolik tarafına vurgu yapmıştır ve sembolik tüketime doğru bir eğilim hızla devam etmektedir (Paterson, 2006, s.24).

Günümüzde yaşam tarzının en önemli göstergelerinden biri olarak görülen Facebook ve Instagram hesabını Tinder hesabıyla birleştirebilen kullanıcılar da birbirleri hakkındaki "romantik" çıkarımlarını, kimliklerini inşa ettikleri anlam ve sembolleri, tüketilen ve sergilenen metalardan yola çıkarak belirlemeye çalışmaktadır. Çünkü daha önce belirtildiği gibi ekonomik çıkar ve toplumsal yükselme, çekiciliği arttıran ya da azaltan etkenlerdir (Malinowsky, 1983, s.33). Statünün, başarı ile eş değer görüldüğü kolektivist bir yapıya sahip olan ve "Batılı olmayan çağdaşlarına acıyarak ve tiksinerek bakan" Avrupa'yı (Toynbee, 2007, s.1) referans alma noktasında statü kavramının aşağılanmanın kaynağı olarak görüldüğü (Morley ve Robins, 1997, s.11) Türkiye'de, Hofstede vd.'nin (2010) kültürel boyutlar modelinin romantik ilişkilere de sirayet etmesi şaşırtıcı değildir. Kimlik bilincimiz aynı zamanda bir arada yaşadığımız insanların yargılarına hapsolmuştur. Hem maddi hem manevi açıdan değerlendirdiğimizde, dünya üzerinde nasıl bir yer kapladığınızla ilgili ciddi endişelerimiz vardır. Dünyada bir yer edinmiş olmamız, bize sevgi gösterilip gösterilmeyeceğini belirlemektedir (Botton, 2010, s.19). Bu nedenlerle statünün ve toplumsal hiyerarşinin bütün işaretleri tüketim yoluyla ortaya çıkmaktadır. Markalar da reklam stratejileriyle her türlü ideoloji ile duygusal bağ kurmaya çalışmaktadır.

Konum tabanlı mobil flört uygulamaları, küresel ve yerel faktörlerin nasıl eklemlendiği meselesi üzerine odaklanmalıdır. Çünkü flört etme biçimleri kültürün en önemli yansımalarından biridir. Fakat, mobil flört uygulamaları geleneksel flört etme biçimlerinin dışında yer alan küresel bir eğilimdir. Bu nedenledir ki, bu uygulamalarda verilen reklam mesajları yerel ve küresel stratejiler arasındaki gerilimi yansıtmaktadır. Günümüzde sosyal ağlar, kültürel kimliğin yaratılmasında kullanılan en önemli araçlardan biri konumuna gelmiştir. Mobil flört uygulamalarında reklamverenlerin ve reklamcıların en sık karşılaştıkları sorun kültür odaklı olabildiği için konum odaklı reklamlar, küresel stratejilerin yanı sıra flört etme biçimlerindeki sosyo-ekonomik ve kültürel etkenler ışığında tasarlanmalıdır. Çünkü, postmodernist kültür teorisinin temel dayanaklarından biri, kültürün insan doğasını şekillendirmesi ve böylece "sosyalleşme" ve öğrenme yollarıyla insanların istediklerinin, reklamların dikte ettirdiklerine uyum sağlamasıdır (Miller, 2012, s.29).

Flört etme pratiklerinin değişmesi bağlamında son otuz yılda Türkiye'de de çarpıcı 
dönüşümler görülmektedir. Neoliberal toplumsal ve ekonomik reformların ve küresel tüketici kültürünün 1980 'lerden bu yana pekişmesiyle birlikte, Türkiye'de önemli toplumsal değişimler yaşandı ve alternatif benlik anlayışlarını ve yeni toplumsal bağları beraberinde getiren daha önce görülmemiş yeni toplumsal bütünleşme tarzları ortaya çıkmıştır. Serbest piyasa ekonomisi ve geniş kapsamlı bir medya ve internet erişimi, Türk gençliğinin aile, kur yapma ve cinsellik gibi konulardaki görüşlerinde ciddi değişimler yaratmıştır. Tüketici kültürü değerleri, başka yerlerde olduğu gibi günümüz Türkiye'sinde de özellikle gençlerin romantik ilişki pratiklerinin cinsel bir nitelik kazanmasında ve cinsel-mahrem ilişkilerin evlilik mülahazalarından uzaklaşmasında önemli bir etkiye sahiptir (Özyeğin, 2011, s.159). 1980’lerde "sözün patlamasıyla" kültür daha önce görülmemiş boyutlarda piyasaya tabi oldu, reklamcılık kısa sürede sınırsız sayıda imgeyi dolaşıma soktu ve Türkiye'de yakın zamana kadar "mahrem" kabul edilen, adı konmamış birçok alan ilk kez 80'lerde kamuoyunun gündemine geldi ve Türkiye'de yaşanan, cinsellik başta olmak üzere özel hayatın, daha çok bir özgürleşme ve bireyselleşme söylemi içinde, bilmek isteyen bir otoriteden bağımsız olarak söze dökülmesi "cinsellik patlamasının" temel dinamiği oldu (Gürbilek, 2001, s.23).

Flört etme biçimlerinin değişimine küresel bir örnek olan Tinder, markalara diğer sosyal ağ uygulamaları gibi kullanıcılarının meslek, eğitim düzeyi, cinsiyet, yaş gibi demografik özelliklerin belirgin bir şekilde ayrıldığı değişkenleri kullanarak yaşam tarzı üzerinden hedef kitleye gerçek zamanlı konum bilgisiyle doğrudan ulaşabilme imkanı sunmaktadır. Bireylerin de konum tabanlı çeşitli uygulamaların yanı sıra GPS (Global Positioning System/Küresel Konumlandırma Sistemi), Google Maps (Google Haritalar) ya da diğer haritalama uygulamalarıyla artık arabalarında ya da yürürken, bilgisayarlarında ya da cep telefonlarında gündelik yaşamın sıradan, önemsiz bir parçasıymışçasına uydu cihazlarını kullanmaya tamamen alıştıklarını görmekteyiz. Dijital yaşam tarzlarının sonucu olarak gündelik hayata yansıyan coğrafi konum tabanlı reklam stratejilerinin ise özellikle yerel markalara önemli fırsatlar yarattığını söyleyebiliriz. Dünyanın önde gelen ekonomi dergilerinden Forbes coğrafi konum tabanlı uygulamalarla ilgili yayınladığı bir makalede, ilk sırada konum tabanlı uygulamaların yerel markalara sağladığı avantajlar yer almaktadır.

Mobil reklamcılık alanının tamamı konum odaklı reklam değildir. Konum odaklı reklam, reklam mesajının alıcının konumu (veya daha teknik olarak cihazın konumu) tarafından belirlenip belirlenmediğine bağlıdır. Bu reklam stratejilerinde iki yaklaşım söz konusudur: İtme ve çekme (the push approach - the pull aproach). Bu kavramlar, geleneksel pazarlama iletişimi bağlamında iyi bilinmesine rağmen, konum odaklı reklam ile ilgili olarak biraz farklı tanımlanmıştır. Dijital pazarlama tarafından etkin bir şekilde kullanılan bu stratejiler, konum odaklı reklam kavramı bağlamında yalnızca nihai tüketiciyi (aracı kurumlar değil) hedef alan reklam ve satış promosyonu (kişisel satış değil) anlamına geldiği için çok daha sınırlıdır. İtme yaklaşımında kullanıcıların izni alınmazken çekme yaklaşımında, kullanıcı bilgiye ulaşmak için zamanı ve yeri seçer (Bruner ve Kumar, 2007). Konum tabanlı reklamlarda her iki strateji de kullanılabilir. Fakat itme stratejisi reklamverenler tarafından daha çok tercih edilse de tüketici bu konum tabanlı reklamlara yönelik negatif tutum sergilemeye eğilimlidir (Shin ve Lin, 
2016). Kullanıcılar, zaman ve yeri seçmek zorunda oldukları Tinder gibi uygulamaları indirdiği zaman reklam iznini de markalara vermektedir. Cep telefonu bağımlılı̆̆ının yaygın olarak tartışıldığı günümüz dijital dünyasında tüketiciler, konum odaklı reklamlar dahil mobil reklamcılığı başka bir spam türü olarak kolayca görebilmektedirler. Bu nedenledir ki reklamlar anlatmak istediklerini sağduyuya hitap ederek kurgulamak zorundadır. Birkaç saniye içinde anlatılanlar, ancak böylelikle hiçbir güçlük çekilmeden herkes tarafından anlaşılabilir. Reklam, sağduyuya konuştuğu ve oradan beslendiği ölçüde, ideolojinin bir aygıtına benzer (Bayramoğlu, 2011, s. 213). Markalar bugün dijital medyanın yükselişi, artan müşteri sadakatsizliği, markalara yönelik azalan güven ve reklamcılığa karşı büyüyen toplumsal rahatsızlık gibi güçlüklerle karşı karşıyadır. Tüketicinin kötü reklam miktarından duyduğu rahatsızlık bağlamında sosyal medya, sıradan web sitelerinden daha kötü durumdadır. Tüketiciler, sosyal medya sitelerindeki reklamları, klasik web sitelerindekinden daha az bilgilendirici ve daha az güven verici buluyorlar. Insanlar sosyal medyada arkadaşlarıyla muhabbet ederken rahatsız edilmek veya dikkatlerinin dağıtılmasını istemiyorlar (Van Dyck, 2017, s.13-14). Bu noktada önemli olan çekme stratejisine uygun reklam tasarımlarının geliştirilmesidir. Konum tabanlı reklamlar, markalara sadece kullanıcılarının yerini değil kullanıcıların neden o yerde olduğunun içeriğine ilişkin bilgiler de sunmaktadır. GlobalWeblndex istatiklerine göre Tinder, 2015 yılında "Tinder Plus" 2017'de ise "Tinder Gold" üyeliklerini başlatmıştır ve 2018 verileri flört etmek için para ödeyen 190 ülkede 4.1 milyon kullanıcı bulunduğunu göstermektedir. Tinder kullanıcılarının yüzde 50'si saat 21.00 'da aktif olurken, kullanıcılar gün içinde ortalama 4 defa uygulamaya giriş yapmaktadır. Bu da en az 4 defa konumlarını güncelledikleri anlamına gelmektedir. Mobil flört uygulamalarında, gerçek zamanlı konum bilgisi, kullanılan uygulamanın içeriği ve flört etme biçimlerinin kültürel yansımaları göz önünde bulundurulan reklam tasarımlarının, tüketicinin reklamları spam gibi algılayarak olumsuz tepkiler vermesini engelleyebileceğini ya da olumsuzluğu azaltabileceğini söylemek mümkündür. Kullanılan uygulamanın içeriği ve gerçek zamanlı konum bilgisine erişim, markaların reklamlarını çekme stratejisine göre tasarlamasını ve tüketiciyi etkileyen algısal faktörleri manipüle etmesini sağlayabilir. Ketelaara vd.(2018) tarafından yapılan bir çalışma da reklam mesaj tasarımlarının, mobil reklamların rahatsız edici algılanması ve mesajın ikna edebilmesi konusunda derin bir etkisi olabileceğini göstermiştir.

Mobil flört uygulamalarını kullanan bireyler, diğer sosyal ağlarda üstü örtülü olan flört etme isteğini beğenilme arzusuyla açık bir şekilde ifade etmektedirler. Mobil flört uygulamaları, fiziksel özellikler, giyim, otomobil, ev dekorasyonu gibi yaşam tarzının sembollerine dair beğenileri reklamlar aracılığıyla inşa edip kullanıcıları markaya yönelik olumlu bir şekilde etkilemek için kullanıcılarına en çok beğenilmek ve beğenmek istedikleri anda reklam mesajlarını iletebilmektedir. Marksist eğitim sosyologlarından Pierre Bourdieu (2015, s. 122-123), beğeni konusunda ekonomik ve kültürel belirlenimin yanında araçsal bedene ve bilinçdışı güdülere vurgu yapar. Ona göre, birey nasıl yapacağını bilir ama neden yaptığını açıklamakta zorlanır. Eğer bir grubun tüm yaşam stilini mobilya ve giyim tarzından okuyabiliyorsak, bu sadece söz konusu bu malların, tercih edilmelerine yol açan ekonomik ve kültürel zorunlulukların nesneleştirilmesi olmalarından dolayı değil, toplumsal ilişkilerin kendilerini bedensel 
deneyimler aracılığıyla çok derin bir biçimde bilinç dışı olarak dayatmasındandır.

\section{Araștırmanın Yöntemi}

Çalışmada, Temmuz 2017-Temmuz 2018 tarihleri arasında Türkiye'de (Kocaeliİstanbul) Tinder'da yayınlanan reklamlar, basit gelişigüzel (random) örneklem tekniğiyle kaydedilmiştir. Bu tekniğin kullanılmasının nedeni Tinder'da yayınlanan reklamların kullanıcı profili gibi tasarlanmasıdır. Tinder kullanıcılarının profillerini sağa ya da sola kaydırırken karşılaşılan erişilebilir reklamlar genellenmiştir. Ankara Üniversitesi mezunu, 37 yaşında, kadın kriterleri kullanılarak bir hesap açılmıştır. Araştırmacının demografik özellikleri doğrultusunda bir hesap açılmasının nedeni, markaların IP adresinden aldıkları veriler doğrultusunda kullanıcıya gönderdikleri reklamların Tinder'da kaydedilen reklamlarla ilişkisini göz önünde bulundurabilmektir. Çalışma süresince kaydedilen 436 reklam, ürün ve hizmet kategorilerine göre ayrılarak, niteliksel ve niceliksel içerik analizi yöntemiyle incelenmiştir.

\section{Araștırma Soruları}

1. Küresel bir eğilim olan mobil flört uygulaması Tinder'da yayınlanan reklamlar ürün ve hizmet kategorilerine göre nasıl tasarlanmaktadır?

2. Tinder'da yayınlanan reklamlarda hangi anlam ve semboller yer almaktadır?

3. Markalar Tinder'da yayınladıkları reklamları konum odaklı reklam stratejilerine göre nasıl tasarlamaktadır?

\section{Verilerin Analizi ve Bulgular}

Tablo 1. Reklamı yayınlanan ürün ve hizmet kategorileri

\begin{tabular}{|c|c|c|c|c|c|c|c|}
\hline Kategoriler & 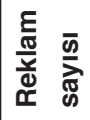 & बें & $\begin{array}{l}\bar{\Phi} \\
\Phi \\
\vdots \\
\vdots\end{array}$ & Kategoriler & 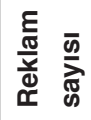 & बे & 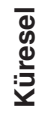 \\
\hline $\begin{array}{l}\text { Alışveriş(giyim/ iç } \\
\text { çamaşııı/mayo/takı/çanta) }\end{array}$ & 60 & 31 & 29 & Emlak & 11 & 9 & 2 \\
\hline Tatil (Spa/otel/ulaşım) & 49 & 29 & 20 & $\begin{array}{l}\text { Medya (Gazete/dergi/ } \\
\text { haber sitesi/kanal) }\end{array}$ & 20 & 5 & 15 \\
\hline $\begin{array}{l}\text { Eğlence (Konser/müzik/ } \\
\text { dans/etkinlik/uygulama) }\end{array}$ & 30 & 13 & 17 & $\begin{array}{l}\text { Otomotiv(Araç satış/ } \\
\text { kiralama/sürücü kursu) }\end{array}$ & 13 & 12 & 1 \\
\hline $\begin{array}{l}\text { Eğitim(Lisans/Yüksek } \\
\text { lisans/Doktora/Sertifika } \\
\text { Programları/Sempozyum/ } \\
\text { Yabancı dil eğitimi/ } \\
\text { Kariyer) }\end{array}$ & 77 & 23 & 54 & Elektronik eşya/teknoloji & 14 & 9 & 5 \\
\hline Bilgisayar oyunu & 33 & 2 & 31 & Astroloji/fal & 3 & 2 & 1 \\
\hline
\end{tabular}




\begin{tabular}{|l|c|c|c|l|c|c|c|}
\hline Spor/Spor malzemeleri & 31 & 8 & 23 & $\begin{array}{l}\text { Estetik/kozmetik/diyet/ } \\
\text { sağlık }\end{array}$ & 27 & 22 & 5 \\
\hline Dekorasyon/Ev işleri & 23 & 16 & 7 & Bebek/çocuk & 10 & 4 & 6 \\
\hline Finans & 27 & 27 & & Yiyecek/içecek & 8 & 6 & 2 \\
\hline TOPLAM & 436 & \multicolumn{6}{l}{} \\
\hline
\end{tabular}

Coğrafi konum tabanlı sosyal ağ uygulaması Tinder'da kaydedilen 436 reklamın 197 tanesi (\%45) lüks ve sembolik tüketimle ilişkili olan alışveriş sitesi/giyim/ iç çamaşırı/ mayo, takı/çanta (60-\%30), tatil (49-\%25), estetik/kozmetik (27-\%14), dekorasyon (23-\%12), finans (27-\%14) ve emlak (11-\%6) sektörüdür. Türkiye'de en lüks markalar arasında kendini konumlandırmış olan Beymen reklamı, lüks tüketim ve aşk arsındaki ilişkiye en keskin örneklerden birisidir. Romantik ilişkilere işaret eden anlam ve sembollerin kullanıldığı reklamlar tatil kategorisinde yoğunlaşırken, estetik ve kozmetik kategorisindeki reklamlar, bireysel "eksiklik" olarak inşa ettiği anlam ve sembollerle tüketiciyi manipüle etmeye yöneliktir. 


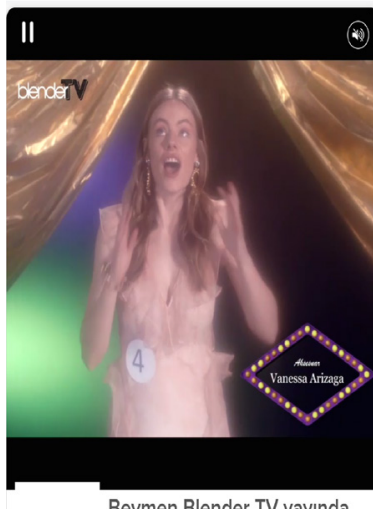

BEYMEN

Beymen Blender TV yayında

Sola değil hemen yurart kaydrt

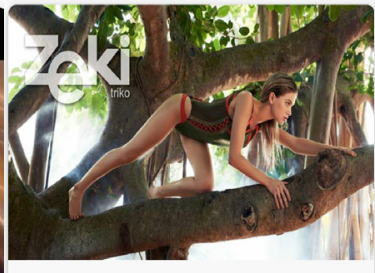

ZEKITRIKO.COM.TR

zeld Zeki 2018 Yaz Koleksiyonu

Doğanın renklerl ile sofistike detayları birleștirerek..

Şimdi Alışveriş Yap
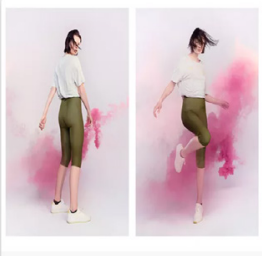

OYSHO.COM

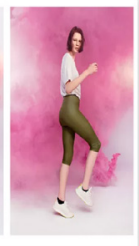

Oysho.com'da geçerli \%10 indirim оэно kodunuzu alın! Sponsorlu (1)

Haber bültenimize hemen kaydolarak, ilk siparișini..

Daha Fazla Bilgi Al

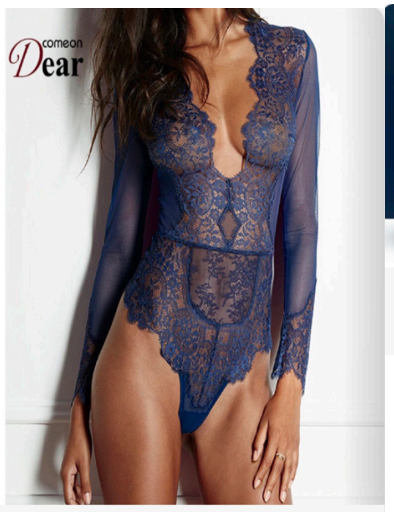

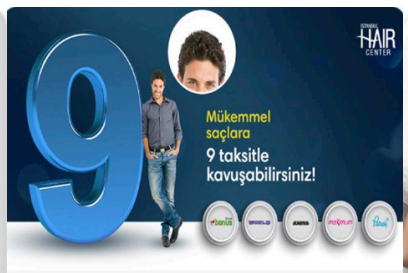

ISTANBULHAIRCENTER.COM

FHAIR

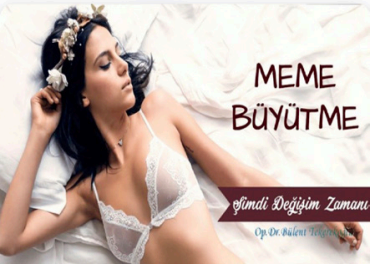

BULENTTEKEREKOGLU.COM.TR

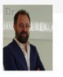

Book Now

Learn More

AliExpress Shopping A...

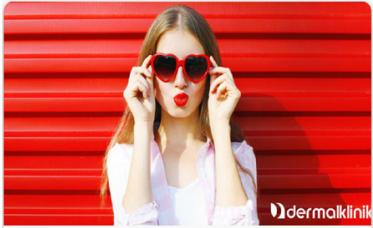

EN.DERMALKLINIK.COM

Non-surgical Eyelid Aesthetics,

Filler, Botox and more..

Everything you wonder about aesthetic and beaut..

Learn More

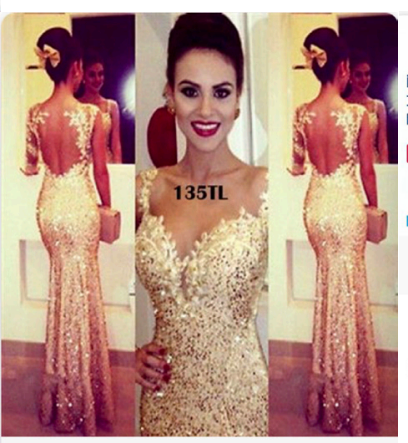

Ücretsiz Kargo

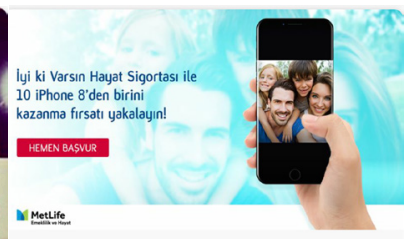

DENIZBANK.COM

iPhone8 Kazanma Firsatı!

lyi ki Varsın Hayat Sigortasina hemen bașvurun, k...

Şimdi Başvur

$\operatorname{Tr}$ Minanna

Resim 1. Lüks ve sembolik tüketimle ilişkili reklam örnekleri 
Tablo 2. Reklam metin örnekleri

\begin{tabular}{|c|c|}
\hline Beymen & $\begin{array}{l}\text { Beymen Blender TV yayında- Sola değil hemen yukarı } \\
\text { kaydır! }\end{array}$ \\
\hline Modanisa & $\begin{array}{l}\text { Ayakkabı ve çanta favorileri- parıl parıl aksesuarlar, şık } \\
\text { topuklular } \\
\text { Yaz gecesi ışıltısı abiyeler } \\
\text { Anneler Günü'ne özel fırsatlar- Annen için en güzel } \\
\text { hediyeleri senin için derledik! } \\
\text { Beverly Hills Polo Club\&Laura Ashley } \\
\text { Davetlere hazır mısın? Şimdi incelemeye başla, Davet } \\
\text { sezonu açıdı hazır mısın? }\end{array}$ \\
\hline Matraş & $\begin{array}{l}500 \text { TL ve üzeri Cüzdan hediye ediyoruz! } \\
\text { Beklenen Anneler Günü kampanyası başladı! Tüm } \\
\text { ürünlerde \%70 }\end{array}$ \\
\hline Oysho & Oysho.com'da geçerli \%10 indirim kodunuzu alın! \\
\hline Zeki Triko & $\begin{array}{l}\text { Zeki } 2018 \text { yaz koleksiyonu-Doğanın renklerini sofistike } \\
\text { detaylarla birleştirerek... }\end{array}$ \\
\hline Nude Glass & Yepyeni başlangıçlar için hediyeler... \\
\hline Cittur & $\begin{array}{l}\text { Taste of Paris Özel Gezisi } \\
\text { Tatilinizi Beraber Planlayalım }\end{array}$ \\
\hline $\begin{array}{l}\text { Clarion Hotel İstanbul } \\
\text { Mahmutbey }\end{array}$ & Hayatın kalbinde, konforun zirvesinde \\
\hline Trivago & $\begin{array}{l}\text { Belek'in keyfini çıkar } \\
\text { Belek'ten Jakuzili odalar }\end{array}$ \\
\hline Venividi Göz & Lazerle uyumsuz olan gözlere akıllı lens \\
\hline İstanbul Hair Center & Mükemmel saçlara 9 taksitle kavuşabilirsiniz! \\
\hline Bülent Tekerekoğlu & $\begin{array}{l}\text { Göğüs Büyütme Ameliyatı- Meme estetiğiyle istediğiniz } \\
\text { görünüme sahip olabilirsiniz. } \\
\text { Şimdi değişim zamanı }\end{array}$ \\
\hline CardFinans & Hayat aldıklarından fazlasıdır \\
\hline Sinpaş & $\begin{array}{l}\text { Aydos Country'de AŞK ev'liliği } \\
\text { Simpaş'tan kiracı kalamayacağınız büyük fırsat }\end{array}$ \\
\hline
\end{tabular}

Çalışmada, cinsellik ve bedenin vurgulandığı 42 (\%10) reklam kaydedilmiştir. Romantik aşk ve birlikteliğe işaret eden anlam ve sembollerin kullanıldığı reklam sayısı ise 20 'dir (\%5). 

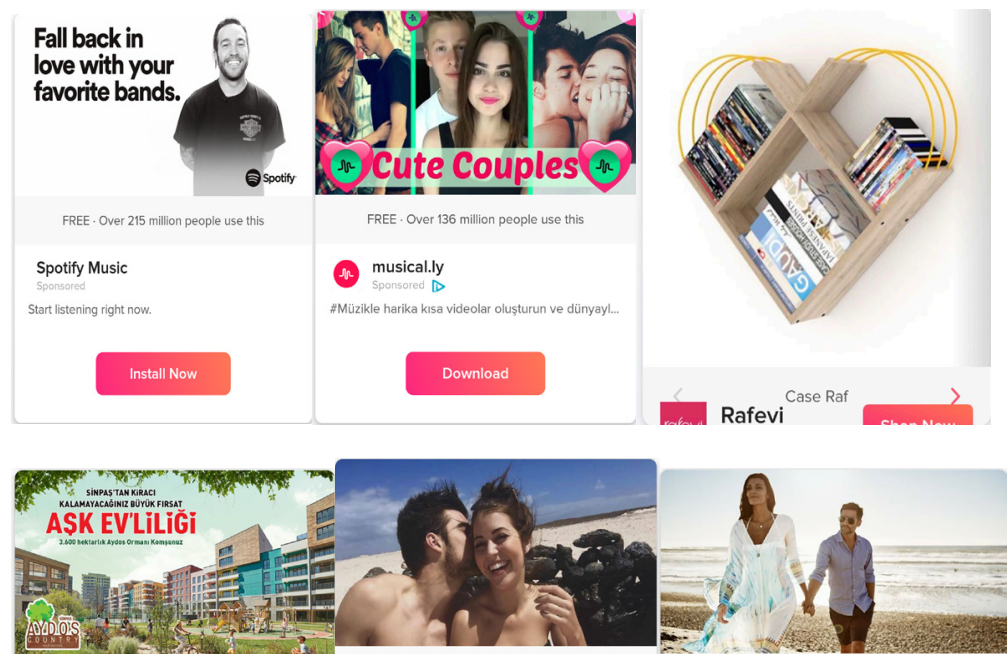

AYDOSCOUNTRY.CON

MADEINSHOREDITCH.CO.UK

WEEKENDS.BOOKHYATTHOTELS.COM

Aydos Country'de Aşk EV'liliği

1 yll kirada yașayın, sonra doğasına așik olacağııız..

Daha Fazla Bilgi Al

The Inner Circle: It's not elitist,

liS it's just a dating app with fewer weirdos

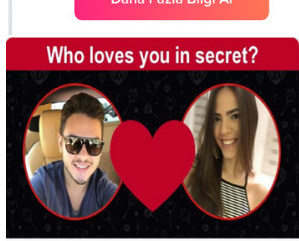

EN.BIGTESTS.CLUB

Who loves you in secret? i. Sponsored ()

Who loves you in secret?

$$
\text { Open Link }
$$

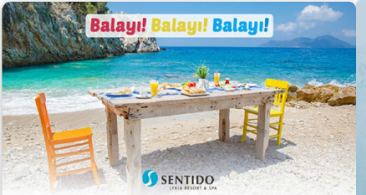

LIBERTYHOTELSLYKIA.COM

SiZ DE YERINIZI ALIN!

Hayalinizdeki Balayı Tatilini Kaçırmayın! Liberty Hot.

Șimdi Rezervasyon Yap
Sign Up

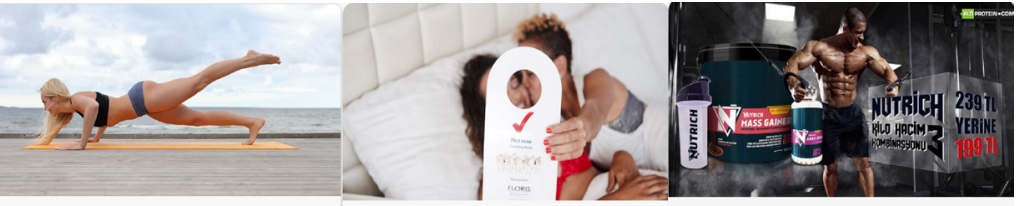

DAILYOM.COM

IGLTA.ORG

IGLIA

Fit and Fierce Over 40

This is how to get strong and youthful in just $20 \mathrm{mi...}$

Learn More

Resim 2. Cinsellik, beden ve romantik aşka işaret eden reklam örnekleri 
Öte yandan geleneksel romantik ilişkilerin dışında tek gecelik ilişkilere vurgu yapan bir uygulama olan Tinder'da, karışık ve anlaşılması güç olan noktalardan biri gibi görünen fakat kültürün reklamlara yansımasını açık bir şekilde ortaya koyan reklamlara da rastlanıımıştır. Bebek, çocuk bakımı ve aile kurumuna ilişkin reklamların yanı sıra tesettür online satış sitesi "Modanisa" reklamları, Tinder'da kültürün etkisinin olabileceğinin örneklerinden birisidir. Mobil flört uygulaması Tinder'da, muhafazakâr değerlere ve geleneksel evlilik kurumuna uygun tasarlanmış 16 (\%4) reklam kaydedilmiştir.

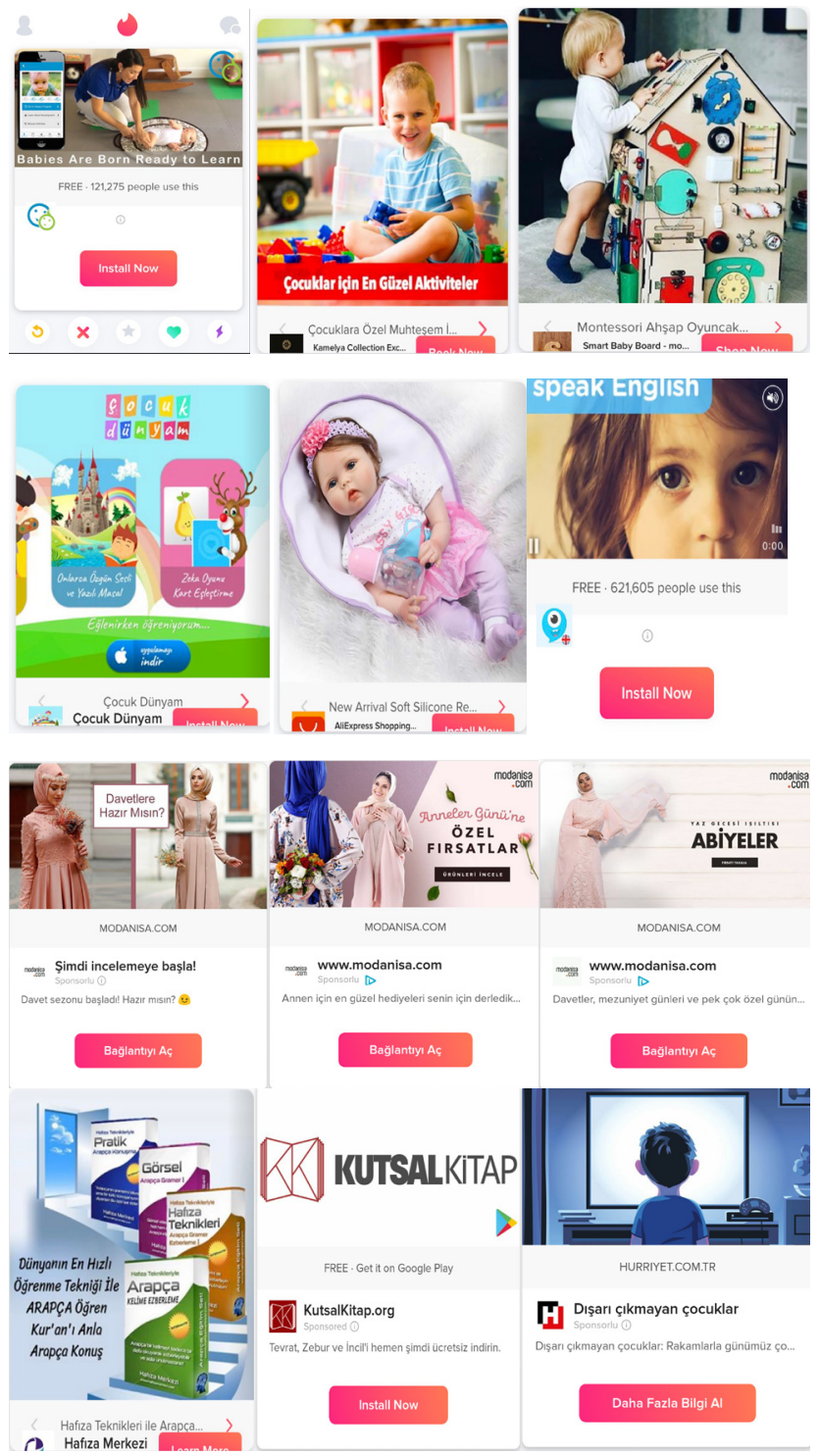

Resim 3. Muhafazakâr değerlere ve geleneksel evlilik kurumuna uygun tasarlanmış reklam örnekleri 
Çalışmada dikkat çeken bir diğer reklam kategorisi ise eğitimdir. İncelenen 436 reklamdan 76'sı (\%17) eğitim kategorisinde kaydedilmiştir. Bu reklamların 17'si (\%22) dil eğitimi (İngilizce), 11 'i (\%14) üniversite eğitimi, 42'si (\%55) kongre, sertifika programı, kariyer ve kişisel gelişim kategorilerindedir. Ayrıca, 51 (\%67) reklam İngilizce, 26 (\%6) reklam Türkçedir.

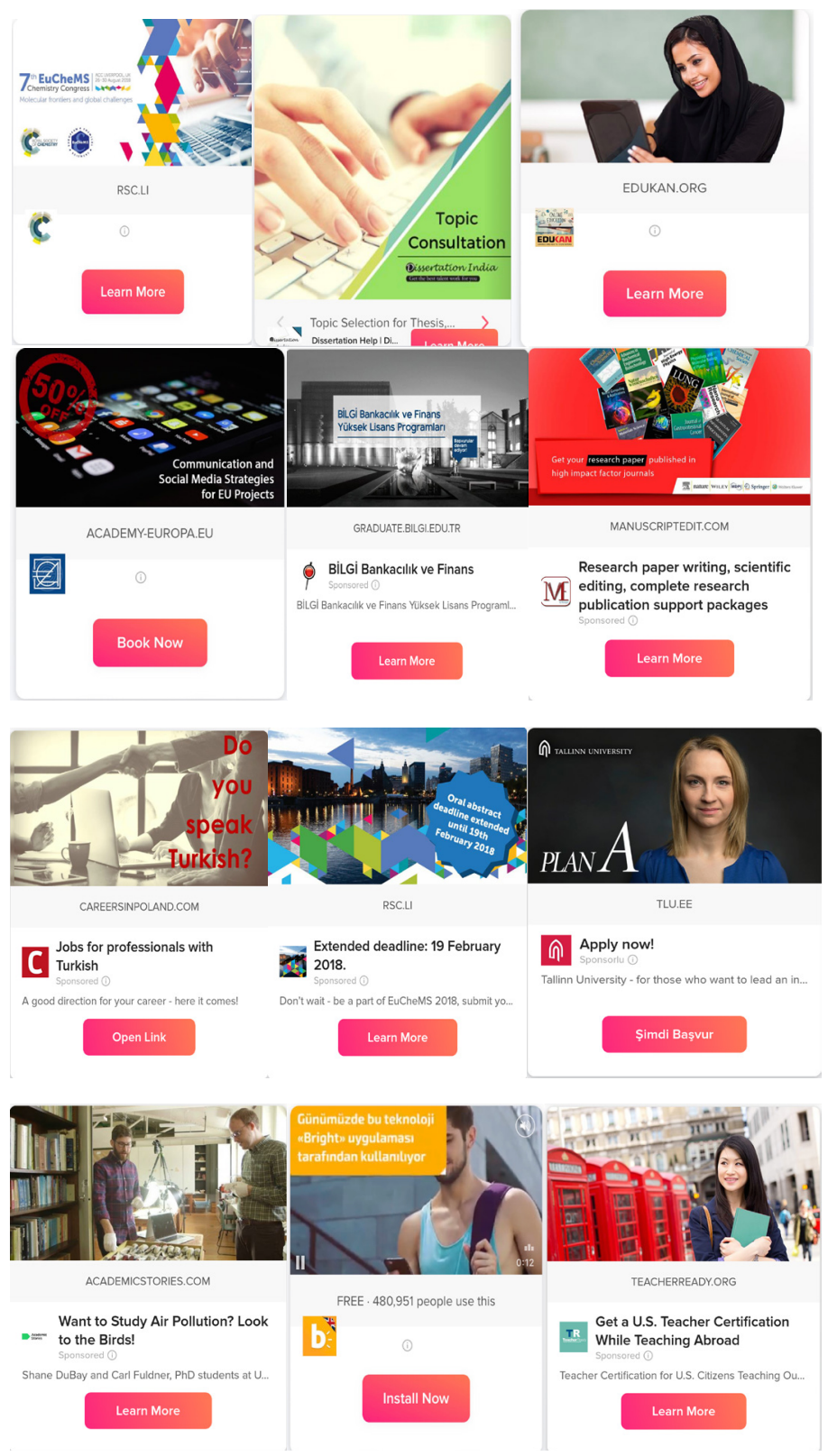

Resim 4. Eğitim kategorisinde kaydedilen reklam örnekleri 
Tablo 2. Reklam metin örnekleri

\begin{tabular}{|c|l|}
\hline \multicolumn{1}{|c|}{ IDP } & $\begin{array}{l}\text { Birleşik Krallık'ta mı okumak istiyorsunuz? Eylül } \\
\text { başvurularını kaçırdınız mı? IDP ile üniversitenize bu ocakta } \\
\text { başlayabilirsiniz! }\end{array}$ \\
\hline Hafıza Merkezi & $\begin{array}{l}\text { Dünyanın en hızlı öğrenme tekniği ile ARAPÇA öğren Kur'an’ı } \\
\text { anla Arapça konuş } \\
\text { Dünyanın en hızlı kelime ezberleme tekniği ile Ingilizce } \\
\text { kelime ezberle }\end{array}$ \\
\hline Yenibiriş.com & Binlerce satış iş ilanları için hemen başvur! \\
\hline Berlitz Dil Okulu & Ingilizceyi herkes anlıyor! Siz konuşun! \\
\hline Disertation India & $\begin{array}{l}\text { Topic Consultation - Dissertation Help } \\
\text { Konu Danışmanlığı - Tez Yardımı }\end{array}$ \\
\hline Academy-Europa & $\begin{array}{l}\text { Communication and Socil Media Strategies for EU projects } \\
\text { AB projeleri için iletişim ve sosyal medya stratejileri }\end{array}$ \\
\hline Blinkist & $\begin{array}{l}\text { The 7 habits of Highly Effective People- Etkili insanların 7 } \\
\text { alışkanlığı } \\
\text { The average CEO reads more than 60 books per year. } \\
\text { Ortalama bir CEO yılda 60'tan fazla kitap okuyor. }\end{array}$ \\
\hline Academics stories & $\begin{array}{l}\text { Turning Live Bacteria into USB Drives - Canlı Bakterileri USB } \\
\text { sürücüsüne dönüştür } \\
\text { Want to study air pollution? Look to the birds! } \\
\text { Hava kirliliğini incelemek ister misin? Kuşlara bak! }\end{array}$ \\
\hline $\begin{array}{l}\text { Do you speak Turkish? Jobs for professionals with Turkish? A } \\
\text { good direction for your career - here it comes! } \\
\text { Türkçe konuşmayı biliyor musun? Türkçe bilen profesyoneller } \\
\text { için iş imkânı. Kariyeriniz için iyi bir yön - işte geliyor! }\end{array}$ \\
\hline
\end{tabular}

Tinder'da incelenen 436 reklamın 218'inin (\%50) yerel, 218'inin (\%50) ise küresel olduğu belirlenmiştir. Öte yandan coğrafi konuma yakınlık açısından uyumlu (İstanbulKocaeli) yayınlanan bölgesel reklamların sayısı ise sadece 28 'dir (\%13). Coğrafi konuma yakınlık düzeyinde uyumlu bu reklamlar, emlak (8-\%29), eğitim (5-\%18), sağlık ve estetik (5-\%18) alanlarında yoğunlaşmaktadır. Coğrafi konuma ve kullanılan uygulamanın özelliklerine uygunluk ve tüketici davranışı arasındaki ilişkiyi inceleyen çok az sayıda araştırma bulunmaktadır. Lee, Kim ve Sundar (2015) tarafından yapılan bir araştırma, kişiselleştirme ve coğrafi olarak uygunluğun konum tabanlı reklamlara karşı pozitif yönde tutumu harekete geçirmek için etkili stratejiler olduğunu göstermiştir. Bu araştırmaya göre "x sokaktaki mağazamızı ziyaret edin, \%25 indirim kazanın" gibi reklam içerikleri ya da sunulan indirim kuponları ürün ya da hizmete yönelik olumlu tutum geliştirme yönünde etkili olabilmektedir. Çalışma süresince 
kaydedilen reklamlarda bu yönde bir stratejiye rastlanılmamıştır. Reklam mesajlarının coğrafi konuma uyumlu tasarlanmadığı dikkat çekmektedir. Sadece iç giyim markası Oysho dijital reklam stratejisine uyumlu olan "Oysho.com'da geçerli \%10 indirim kodunuzu alın” mesajını vermektedir. Çalışma süresince indirim kuponu gibi mesajlar ya da adrese ilişkin bilgilerden daha çok ürüne ya da hizmete yönelik reklam metinleri kaydedilmiştir. Kaydedilen 28 reklamdan sadece 5 reklam metninde konuma ilişkin detaylı olmayan bilgiler verilmiştir.

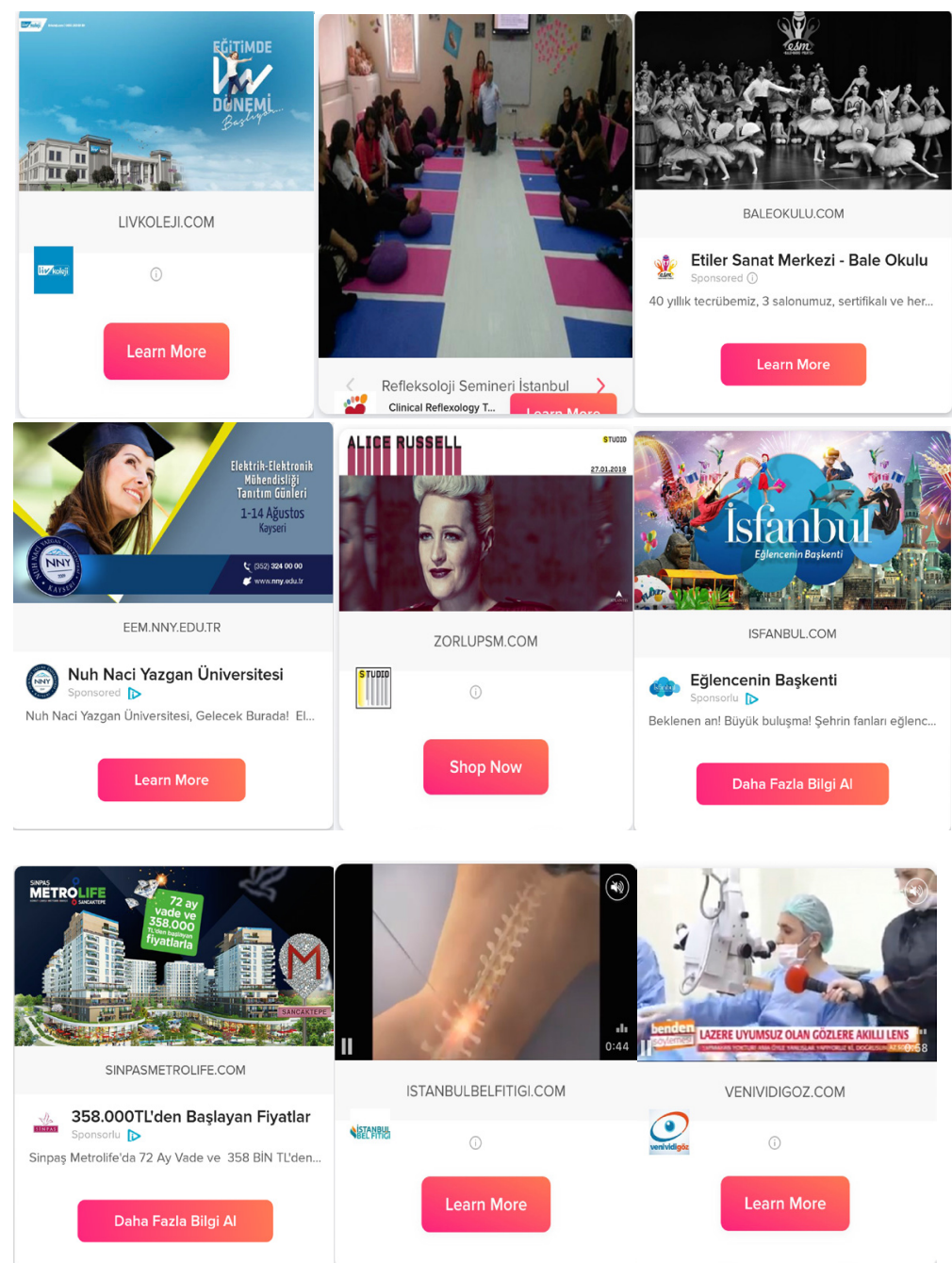




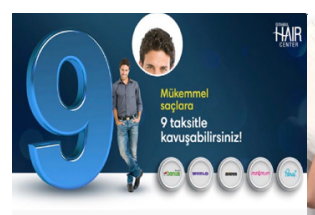

ISTANBULLHAIRCENTER.COM

WAIR

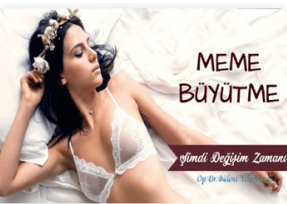

BULENTTEKEREKOGLU.COM.TR

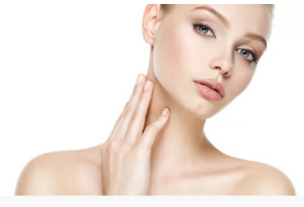

CLINIMED.COM.TR

O(532) 2751130

Gıdı. Kampanya ve indirimlerimizi kaçırmayın! Ücret
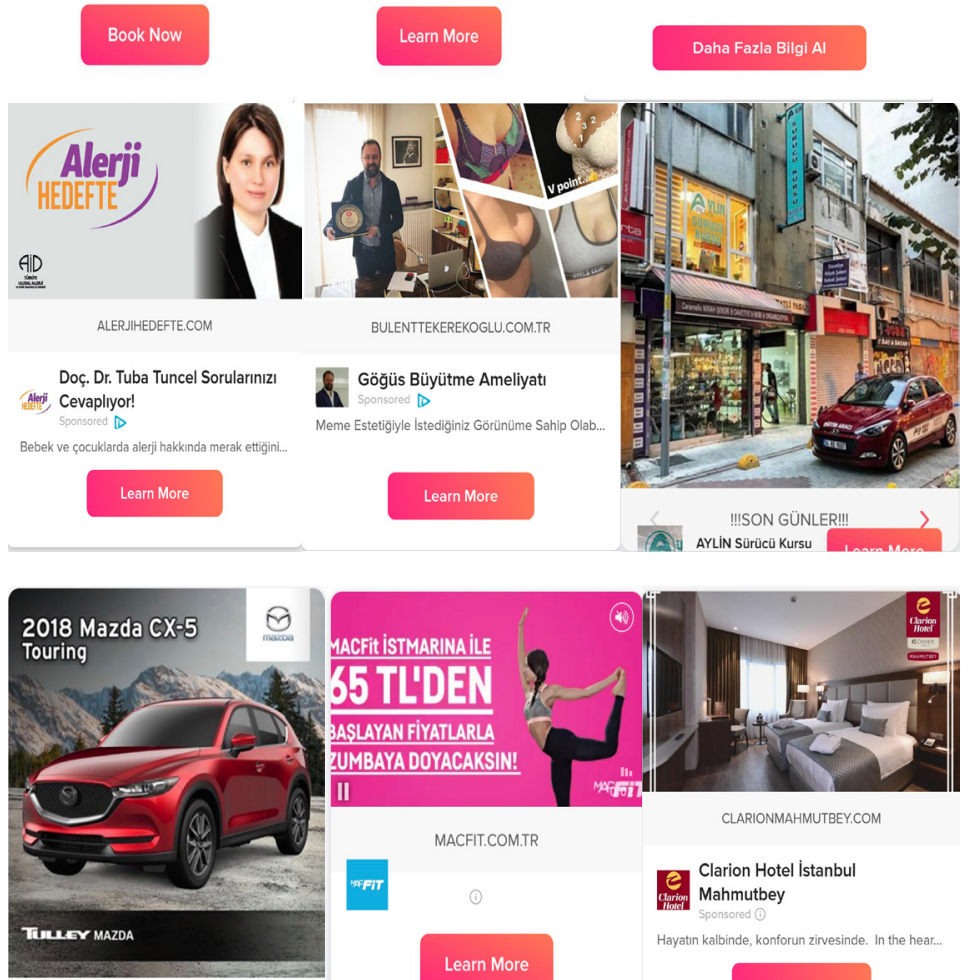

Learn More Book Now

$\$ 149 / \mathrm{mo}$ For 36 Months

حullev Mazda

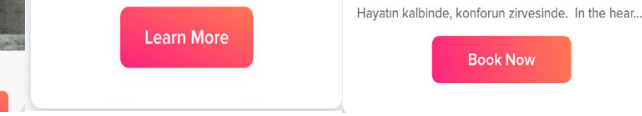

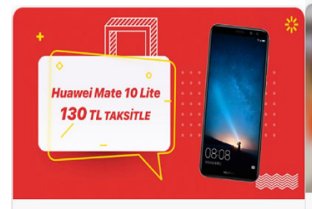

CETINLERAS.COM

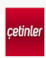

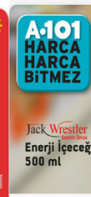

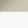

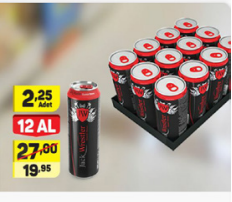

SGU.COM.TR

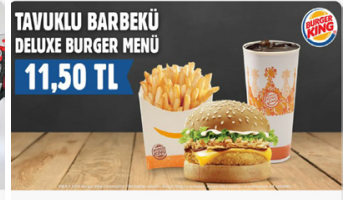

ÜCRETSIz 1 milyondan fazla kiși bunu kullanyor

5. Jack Wrestler

Jack Wrestier özel fiyat ile a101llerde.

ㄱ. Yemeksepeti - Yemek Siparişi Yensoriu

Şimdi Sipariş Ver

Resim 5. Coğrafi konuma uyumlu reklam örnekleri 


\section{Tartıșma}

Geç kapitalist tüketim toplumunda, anlamlar ve semboller tüketim ve sergilenen metalardan ayrılamaz, basit bir şekilde azaltılamaz. Alışkanlığa bağlı olarak gündelik hayatımızda bu anlam ve sembolleri kimliğimizi inşa etmek ve sürdürmek için kullanmaktayız. Yaşam tarzlarının değişmesi, tüketim kalıplarının değişmesini de zorunlu kılmıştır (Paterson, 2006, s.30). Tinder gibi sosyal ağlar yeni sosyalleşme ve tüketim kalıplarının gelişmesinde katalizör rolü üstlenmektedir. Bu nedenle tüketim mal ve hizmetlerini üretenlerin değişen duyarlıklara hizmet verirken, ürünlerinin simgesel anlamları konusunda duyarlı davranmaları gerekmektedir (Chaney, 1999, s.39).

Kültür kuramcısı Sombart, üretim biçimlerine damga vuran "Lüks" kavramına çok temel bir rol biçer. Bu öyle bir fenomendir ki, onunla daima, gereksiz olan şeyler bağdaştırılır, lüks dediğimiz şey lüzumsuzlukla ilişkilendirilir. Fakat, lüks öyle sebepsiz yere, üstelik tek başına orta çıkmamıştır. Sombart'a göre (2016, s.9) lüksün, zevk sahibi kadınlar aracılığıyla şekillendirilip teşvik edilmesi gerekti ki, o gün bugündür olduğu şeyi olabilsin. Nitel bir lüks biçimi ancak kadınların yönetimi altında ortaya çıkabildiğini iddia eden Sombart'a göre kadınlar lüks taslağını oluşturdu; lüksün rafineleşmesini ve hatta "aşırı incelenmesini" ve yayılmasını sağladı. Fransız düşünür Lefebre de (2010, s.20) gündelik hayatın analizinde kadınların önemine dikkat çekmektedir. Ona göre, gündelik hayat genel olarak "kadınlar" üzerinde tüm ağırlığını hissettirmektedir; kadınlar, toplumsal sınıf ve gruplara göre çok önem taşıyan farklılıklara rağmen, gündelik hayata erkeklerden daha fazla maruz kalırlar. Onların durumu gündelik hayatı özetlemektedir.

Günümüzde birey, insanları etkileyebilmek yani diğerlerinde iyi bir izlenim bırakmak ve sahte özelliklerle gösteriş yapmak için satın almaktadır. Modern tüketiciler, kendini pazarlamaya ve tükettikleri mal ve hizmetler aracılığıyla ne kadar sağlıklı, zeki ve popüler olduklarını abartılı bir şekilde göstermeye çaba sarf ederler. Çalışmalar, erkelerin cinsellikle daha çok ilgilendikleri dönemde tüketimlerini çarpıcı bir şekilde arttırdıklarını onaylamaktadır. Öte yandan elde edilen bulgular erkeklerin kadınların gösterişçi tüketimine çok az dikkat ettiklerini göstermektedir (Miller, 2012, s. 18). Sombart (2016, s.10), "Dişilik" güdümlü olan yeni lüksü açıklamak için başka bazı önkoşulların da gerekli olduğunu "zenginliğin doğduğu, aşk hayatının da doğal ve özgür (ya da arsız) bir biçimde geliştiği yere lüksün de hâkim” olacağını iddia etmektedir. Ayrıca, bedensel kozmetik, giyim veya ev dekorasyonu gibi nesnel ve öznel estetik konumlanmalar, tutulacak bir saf ya da korunacak bir mesafe olarak, toplumsal uzamda işgal edilen konumu sınama ya da olumlama fırsatlarıdır (Bourdieu, 2015, s. 93). Bu nedenlerle Tinder'da kaydedilen reklamların yüzde 45 'inin lüks ve sembolik tüketimle ilişkili olduğunu söyleyebiliriz. Daha önce de vurgulandığı gibi sembolik tüketim bağlamında coğrafi konum tabanlı sosyal ağ uygulaması Tinder, özellikle yerel markalar için önemli fırsatlar yaratabilmektedir. Çünkü bir yandan görsel-işitsel üretimin yurtsuzlaştığına ve ulus-aşırı yayın sistemlerinin geliştiğine, bir yandan da yerel üretim ve dağıtım şebekeleri yönünde önemli gelişmelere hâlâ tanık olmaktayız. Kitlesel piyasalar parçalanarak belirli izleyici kesimlerinin büyük medya ve reklam 
şirketleri tarafından hedeflenebilmesi kolaylaşmıştır (Morley ve Robins, 1997, s. 18).

Ayrıca çalışmada eğitim kategorisine ilişkin kaydedilen reklamların oranı dikkat çekmektedir. Bu oranın yüksek (\%17) olmasının bir nedeni internet arama geçmişi ve Facebook ve Instagram aracılığıyla ulaşılan kişisel verilerdir. Eğitim kategorisinin oranının yüksek olmasının bir başka nedeni ise eğitimin statü/kazanç ile ilişkisidir. Bourdieu'a göre, (2015, s. 20-41) toplumsal eşitsizliğin kalıcılığını açıklayan faktörler arasında ilk olarak temelde var olan değerlerin, sermayenin aktarımı vardır. Günümüzde ekonomik sermayenin yanında başka bir çeşit sermaye vardır: kültürel sermaye. Ona göre, kültürel sermaye öncelikle dil demektir, bir nevi dile hükmetme yetisidir. "Kültürlü" bir ailede edindiğiniz şeydir. Sınırlıdır ve eşitsiz olarak dağıtılmıştır. Ve sermayesi daha çok olanlar, bu eşitsiz dağılım sebebiyle kıtlığa bağlı olarak kazanç elde ederler. Eğitim sermayesi (sahip olunan diplomalarla ölçülen) hem aile tarafından sağlanan kültürel aktarımın hem de okul tarafından sağlanan kültürel aktarımın birikmiş etkilerinin ürünüdür.

\section{Sonuç}

Modern toplumda birçok işlevi bulunan ve kültürel olarak merkezi bir öneme sahip romantik aşk ideolojisinin doğal yönelimleri ışığında ortaya çıkan flört etme pratikleri toplumdan topluma farklılık göstermektedir. Günümüzde mitik anlamını kaybeden romantik aşk ve cinsel istek birbiriyle bağlantılı bir şekilde çoğu zaman evrensel olabiliyorken, flört etme pratikleri kültürel bir deneyim olarak inşa edilmektedir. Kısa dönemli postmodern romantik ilişkiler, toplumsal olarak kabul gören kişisel anlam ve deneyimleri biçimlendirirken reklamlar aracılığıyla yeniden üretilen anlam ve semboller, bu ön kabullere göre tasarlanmaktadır. Romantik aşka yapısalcı perspektiften bakıldığında, Batı odaklı aşk ideali ile kapitalizm arasındaki sarsılmaz ilişkinin hem küresel hem de yerel reklam stratejilerine yansıması ise kaçınılmazdır.

Her gün milyonlarca cep telefonu ya da bilgisayar kullanıcısının çeşitli nedenlerden dolayı kullandığı konum tabanlı uygulamalar aynı zamanda dijital yaşam tarzlarının bir göstergesidir. Toplumsal olarak inşa edilen flört etme biçimleri ve dijital yaşam tarzlarına ilişkin verilere ve konum bilgisine paralel olarak tasarlanan reklamların başarısı ise söz konusu değişkenlerin sistemli olarak bir araya getirilmesine bağlıdır. Özellikle gerçek zamanlı konum bilgisi aynı zamanda mekânsal davranışa ilişkin veriler sağlamaktadır. Lüks bir restoran, alışveriş merkezi, otobüs durağı ya da evinde olan tüketicinin kullandığı uygulamanın içeriğine ve bulunduğu konumun sosyo-kültürel ve ekonomik algısına göre çıkarımlarda bulunmak mümkün olabilir. Bu bakımdan "kim, ne zaman, neden, nerede" sorularının yanıtı, toplumsal hiyerarşiyle ilişkili bir biçimde tüketicileri spesifik olarak hedeflemesi amaçlanan konum odaklı reklam stratejilerinin kilit noktasıdır. Öte yandan, kişisel güvenlik ve mahremiyet hakkının özellikle ekonomik düzlemde tartışıldığı günümüzde tüketiciye ilişkin verilere ulaşmada markalara sonsuz imkânlar sunulmaktadır. Sosyal ağ kullanıcılarının değeri her geçen gün artmaktadır ve kullanıcılar bu değeri eğlence ve statü odaklı sosyal ağ kullanımlarıyla kendileri oluşturmaktadır. Her ne kadar bu tartışmalar devam etse de dijital yaşam tarzlarının 
tüketimle ilişkisi engel tanımadan devam edecek gibi görünmektedir.

Söz konusu bu ilişkiyi değerlendirebilmek için Tinder'da incelenen 436 reklamın \%50'sinin yerel, \%50'sinin ise küresel olduğu belirlenmiştir. Coğrafi konuma yakınlık açısından uyumlu yayınlanan reklamların yüzdesi ise sadece 13'tür. Emlak, eğitim, sağlık ve estetik alanlarında yoğunlaşan bu reklamların tasarımında yukarıda altı çizilen konum odaklı uygulamaların sunduğu verilerden yeterince yararlanılmadığı görülmektedir.

Belirlenen diğer reklam kategorilerinde ise varsayıldığı gibi lüks-sembolik tüketimle ve kültürel sermayeyle ilişkili reklamlar kaydedilmiştir. Kullanıcıların maruz kaldığı reklamların \%45’i lüks ve sembolik tüketime işaret ederken, \%17 oranıyla eğitim dikkat çeken bir diğer kategoridir. Lüks ve sembolik tüketimin altının çizildiği reklamlar, alışveriş sitesi/giyim/iç çamaşırı/mayo, takı/çanta, tatil, estetik/kozmetik, dekorasyon, finans ve emlak sektöründe yoğunlaşmaktadır. Mitik anlamda inşa edilen aşkın dünyevileşmesiyle yaratılan yeni kadın ve erkek tipine dayatılan yaşam tarzları, kapitalist lüks kültürünü yükseltmeye devam etmektedir. Tinder'da yayınlanan lüks ve sembolik tüketimle ilişkili reklamların, "potansiyel partnerinizle, hemen başvuru yapabileceğiniz bir kredi kartı ile lüks markalardan giyinip, saç ektirip ya da uzatıp, göğüslerinizi büyütüp, zayıflayıp, tatile gidebilirsiniz" mesajına uygun bir şekilde tasarlandığı görülmektedir. Bireysel "eksiklik" olarak inşa edilen anlam ve sembollerle tüketiciyi manipüle etmeyi amaçlayan estetik ve kozmetik kategorisinde kaydedilen reklamların oranı \%14'tür. Eğitim kategorisinde ise kongre, sertifika programı, kariyer, kişisel gelişim, dil ve üniversite eğitimine ilişkin reklamlara rastlanmaktadır. Verilerin analizinde belirtildiği gibi eğitimin statü ile iliş̧ilendirilmesinden dolayı flört uygulaması Tinder'da benlik sunumunda sahip olunan diplomalar ve bilinen yabancı diller önem kazanmaktadır.

Öte yandan cinsellik ve bedenin vurgulandığı reklamlar \%10, tatil kategorisinde yoğunlaşan romantik aşkı yeniden üreten reklamlar \%5, muhafazakâr değerlere ve geleneksel evlilik kurumuna uygun tasarlanmış reklamlar ise $\% 4$ olarak kaydedilmiştir. Çalışmada varsayıldığı gibi kısa dönemli ilişkileriön plana çıkaran bir flört uygulamasında bile kültürün etkisiyle geleneksel aşk ideolojisinin ve muhafazakâr değerlerin izlerine rastlamaktadır.

\section{Kaynakça}

Badiou, A. ve Truong, N. (2011). Aşka Övgü (O. Türkay, Çev.). İstanbul: Can Sanat Yayınları.

Bauman, Z. (2011). Akışkan modern dünyadan 44 mektup (P. Siral, Çev.). İstanbul: Habitus Yayıncılık.

Bauman, Z. (2012). Akışkan aşk: Insan ilişkilerinin kırılganlığına dair (I. Ergüden, Çev.). İstanbul: Versus Kitap.

Bayramoğlu, Y. (2011). Mars-Venüs/kadın-erkek: Reklamlarda heteroseksizm ve eşcinsellik. C. 
Özbay, A. Terzioğlu ve Y. Yasin (Der.), Neoliberalizm ve Mahremiyet: Türkiye'de Beden, Sağlık ve Cinsellik içinde. İstanbul: Metis Yayınları.

Bennett, A. (2013). Kültür ve Gündelik Hayat (N. Tokdoğan, B. Şenel ve U. Y. Kara, Çev.). Ankara: Phoenix Yayınları.

Berger, P. ve Luckmann, T. (2008). Gerçekliğin sosyal inşâsı: Bir bilgi sosyolojisi incelemesi (V. S. Öğütle, Çev.). İstanbul: Paradigma Yayıncılık.

Bourdieu, P. (2015). Ayrım: Beğeni yargısının toplumsal eleştirisi (D. F. Şannan ve A. G. Berkkurt, Çev.). Ankara: Heretik Yayınları.

Botton, A. (2010). Statü endişesi (A. S. Bayer, Çev.), İstanbul: Sel Yayıncılık.

Bruner, G. C. ve Kumar A. (2007). Attitude toward location-based advertising, Journal of Interactive Advertising. Journal of Interactive Advertising, 7(2), 3-15, doi: 10.1080/15252019.2007.10722127. Erişim adresi: https://www.researchgate.net/publication/242220655_Attitude_toward_Locationbased_Advertising.

Chaney, D. (1999). Yaşam Tarzları (i. Kutluk, Çev.). Ankara: Dost Kitabevi.

Chodorow, N. J. (2007). Duyguların gücü: Psikanalizde, cinsiyette ve kültürde kişisel Anlam (J. Ü. Dirlikyapan, Çev.). İstanbul: Metis Yayınları.

De Rougemont, D. (1983). Çağdaş Çiftin İçinde Bulunduğu Bunalım. A. Krich (Der), Aşkın Anatomisi (M. Harmancı, Çev.) içinde (s. 79-90). İstanbul: Say Kitap.

Debord, G. (1996). Gösteri toplumu (A. Ekmekçi ve O. Taşkent, Çev.). İstanbul: Ayrıntı Yayınları.

Dell, F. (1983). Makine Çağında Aşk. A. Krich (Der), Aşkın Anatomisi (M. Harmancı, Çev.) içinde (s. 45-63). İstanbul: Say Kitap.

Eagleton, T. (2014). Tanrı’nın ölümü ve kültür (S. Dingiloğlu, Çev.), İstanbul: Yordam Kitap.

Funk, R. (2013). Ben ve biz: Postmodern insanın psikanalizi (Ç. Tanyeri, Çev.). İstanbul: Yapı Kredi Yayınları.

Illouz, E. (2013). Aşk neden acıtır (Ö. Çağlar Aksoy, Çev.). İstanbul: Jaguar Kitap.

Goffman, E. (2014). Gündelik yaşamda benliğin sunumu (B. Cezar, Çev.). İstanbul: Metis Yayınları.

Guadagno, R. E, Okdie B. M. ve Kruse, S. A. (2011). Dating deception: Gender, online dating, and exaggerated self-presentation. Computers in Human Behavior, 28(2), 642-647, doi:10.1016/j. chb.2011.11.010. Erişim adresi: www.elsevier.com/locate/comphumbeh

Gürbilek, N. (2001). Vitrinde yaşamak: 1980'lerin kültürel iklimi. İstanbul: Metis Yayınları.

Hofstede, G., Hofstede, G. J. ve Minkov, M. (2010). Cultures and organizations. ABD: McGrawHill

Ketelaara, P. E., Bernritterb, E. S, Woudenberga, T. J., Rozendaala, E., Koniga, R. P., Hühnd, A. E., Gisbergene, M. S. V. ve Janssenf, L. (2018). "Opening” location-based mobile ads: How openness and location congruency of location-based ads weaken negative effects of intrusiveness on brand choice. Journal of Bussiness Research, 91, 277-285. Erişim adresi: https://www.sciencedirect. com/science/article/abs/pii/S0148296318303059 
Lee, S., Kim, K. J. ve Sundar, S. S. (2015). Customization in location-based advertising: Effects of tailoring source, locational congruity, and product involvement on ad attitudes. Computers in Human Behavior. 51, 336-343. Erişim adresi: https://www.sciencedirect.com/science/article/pii/ S0747563215003441

Lefebvre, H. (2010). Gündelik hayatın eleştirisi II: Gündelik hayat sosyolojisinin temelleri (I. Ergüden, Çev.). İstanbul: Sel Yayıncılık.

Malinowsky, B. (1983). İçgüdüden Duyguya. A. Krich (Der), Aşkın Anatomisi (M. Harmancı, Çev.) içinde. İstanbul: Say Kitap.

Mannheim, K. (2002). Ideoloji ve ütopya (M. Okyayuz, Çev.). Ankara: Epos Yayınları.

May, R. (2010). Aşk ve irade (Y. Namer, Çev.). İstanbul: Okuyanus Yayınları.

Miller, G. (2012). Tüketimin evrimi, cinsiyet, statü ve tüketim (G. Vardar, Çev.). İstanbul: Alfa Yayıncılık.

Morley, D. ve Robins K., (1997). Kimlik mekânları, küresel medya, elektronik ortamlar ve kültürel sınırlar (E. Zeybekoğlu, Çev.). İstanbul: Ayrıntı Yayınları.

Niedzviecki, H. (2009). Dikizleme günlüğü. (G. Gündüç, Çev.). İstanbul: Ayrıntı Yayınları.

Özbay, C., Terzioğlu, A. ve Yasin, Y. (Ed.) (2011). Neoliberalizm ve mahremiyet: Türkiye'de beden, sağlık ve cinsellik. İstanbul: Metis Yayınları.

Özyeğin, G. (2011). Arzunun nesnesi olmak: Romans, kırılgan erkeklik ve neoliberal özne. C. Özbay, A. Terzioğlu ve Y. Yasin (Der.), Neoliberalizm ve mahremiyet: Türkiye'de beden, sağlık ve cinsellik içinde. İstanbul: Metis Yayınları.

Paterson, M. (2006). Consumption and everyday life. London \& New York: Routledge/Taylor \& Francis Group..

Phillips, A. (1997). Flört üzerine (Ö. Arıkan, Çev.). İstanbul: Ayrıntı Yayınları.

Ranzini, G. ve Lutz, C. (2017). Love at first swipe? Explaining Tinder self-presentation and motives. Mobile Media \& Communication, 5(1), 80-101, doi: 10.1177/2050157916664559. Erişim adresi: www.journals.sagepub.com/home/mmc.

Shin, W. ve Lin, T. T. (2016). Who avoids location-based advertising and why? Investigating the relationship between user perceptions and advertising avoidance, Computers in Human Behavior, 63, 444-452. Erişim adresi: https://www.sciencedirect.com/journal/computers-in-humanbehavior/ $\mathrm{vol} / 63 \mathrm{suppl} / \mathrm{C}$

Sombart, W. (2016). Aşk lüks ve kapitalizm: Modern dünyanın savurganlığının doğması üzerine (N. Aça, Çev.), Ankara: Pharmakon Yayınevi

Timuçin, A. (2010). Aşkın diyalektiği. İstanbul: Bulut Yayınları.

Toynbee, J. T. (2007). Türkiye ve Yunanistan'da Batı meselesi (K. M. Orağlı, Çev.). İstanbul: Yeditepe Yayınevi.

Zizek, S. (2005). Yamuk bakmak, popüler kültürden Jacques Lacan’a Giriş (T. Birkan, Çev.). İstanbul: Metis Yayınları. 
Zizek, S. (2012). "Zizek Aşkın Felsefesini Anlatıyor". Erişim adresi: https://www.youtube.com/ watch?v=3EnFpfKFG_0.

Forbes Agency Council. (2017). "15 Things You Should Know About Location-Based Advertising". Erişim adresi: https://www.forbes.com/sites/forbesagencycouncil/2017/11/22/15-things-youshould-know-about-location-based-advertising/\#63c0e0891e62.

McGrath, F. (2015). "What to Know about Tinder in 5 Charts". Erişim adresi: https://blog. globalwebindex.com/trends/what-to-know-about-tinder/. 